Journal for ImmunoTherapy of Cancer

\title{
Role of Fc $\gamma$ receptors in HER2-targeted breast cancer therapy
}

\author{
Antonino Musolino, ${ }^{1}$ William J Gradishar, ${ }^{2}$ Hope S Rugo (D) , ${ }^{3}$ Jeffrey L Nordstrom, ${ }^{4}$ \\ Edwin P Rock, ${ }^{4}$ Fernanda Arnaldez, ${ }^{4}$ Mark D Pegram ${ }^{5}$
}

To cite: Musolino A Gradishar WJ, Rugo HS, et al. Role of Fc $\gamma$ receptors in HER2targeted breast cancer therapy. Journal for ImmunoTherapy of Cancer 2022;10:e003171. doi:10.1136/jitc-2021-003171

- Additional supplemental material is published online only. To view, please visit the journal online (http://dx.doi.org/10. 1136/jitc-2021-003171).

Accepted 25 October 2021

Check for updates

(C) Author(s) (or their employer(s)) 2022. Re-use permitted under CC BY-NC. No commercial re-use. See rights and permissions. Published by BMJ.

${ }^{1}$ Department of Medicine and Surgery, University Hospital of Parma, Medical Oncology and Breast Unit, Parma, Italy

${ }^{2}$ Division of Hematology/ Oncology, Northwestern University, Chicago, Illinois, USA ${ }^{3}$ Helen Diller Family Comprehensive Cancer Center, Breast Oncology and Clinical Trials Education, University of California San Francisco, San Francisco, California, USA ${ }^{4}$ MacroGenics, Inc, Rockville, Maryland, USA

${ }^{5}$ Stanford Cancer Institute, Stanford University School of Medicine, Stanford, California, USA

\section{Correspondence to}

Dr Mark D Pegram;

mpegram@stanford.edu

\section{ABSTRACT}

Several therapeutic monoclonal antibodies (mAbs), including those targeting epidermal growth factor receptor, human epidermal growth factor receptor 2 (HER2), and CD20, mediate fragment crystallizable gamma receptor ( $\mathrm{Fc \gamma R}$-dependent activities as part of their mechanism of action. These activities include induction of antibodydependent cellular cytotoxicity (ADCC) and antibodydependent cellular phagocytosis (ADCP), which are innate immune mechanisms of cancer cell elimination. Fc $\gamma \mathrm{Rs}$ are distinguished by their affinity for the Fc fragment, cell distribution, and type of immune response they induce. Activating FcyRIIla (CD16A) on natural killer cells plays a crucial role in mediating ADCC, and activating FcyRlla (CD32A) and Fc $\gamma R$ Rllla on macrophages are important for mediating ADCP. Polymorphisms in Fc $\gamma R$ IIlla and Fc $\gamma R$ Rla generate variants that bind to the Fc portion of antibodies with different affinities. This results in differential Fc $\gamma \mathrm{R}$ mediated activities associated with differential therapeutic outcomes across multiple clinical settings, from early stage to metastatic disease, in patients with HER2+ breast cancer treated with the anti-HER2 mAb trastuzumab. Trastuzumab has, nonetheless, revolutionized HER2+ breast cancer treatment, and several HER2-directed mAbs have been developed using Fc glyco-engineering or Fc protein-engineering to enhance FcyR-mediated functions. An example of an approved anti-HER2 Fc-engineered chimeric mAb is margetuximab, which targets the same epitope as trastuzumab, but features five amino acid substitutions in the $\lg \mathrm{G} 1 \mathrm{Fc}$ domain that were deliberately introduced to increase binding to activating FcyRllla and decrease binding to inhibitory Fc $\gamma R$ Rllb (CD32B). Margetuximab enhances Fc-dependent ADCC in vitro more potently than the combination of pertuzumab (another approved mAb directed against an alternate HER2 epitope) and trastuzumab. Margetuximab administration also enhances HER2-specific B cell and T cell-mediated responses ex vivo in samples from patients treated with prior lines of HER2 antibody-based therapies. Stemming from these observations, a worthwhile future goal in the treatment of HER2+ breast cancer is to promote combinatorial approaches that better eradicate HER2+ cancer cells via enhanced immunological mechanisms.

\section{INTRODUCTION}

Trastuzumab, a humanized human epidermal growth factor receptor 2 (HER2)-directed monoclonal antibody (mAb), increases diseasefree survival (DFS) and overall survival (OS) in early stage HER2-overexpressing/amplified breast cancer and improves progression-free survival (PFS) and OS in metastatic HER2positive (HER2+) disease. ${ }^{2}$ Trastuzumab was the first humanized mAb approved for cancer treatment and the first biologic agent approved for treatment of breast cancer. Since its initial regulatory approval in 1998, it is estimated that trastuzumab has been given to more than 2.5 million women worldwide and is on the WHO's list of essential medicines. Trastuzumab has revolutionized therapy of HER2+ breast cancer. $^{12}$ Both non-immune and immunemediated mechanisms account for trastuzumab's clinical activity. Non-immune-related mechanisms result directly from binding of antibody fragment antigen-binding (Fab) domains to HER2 receptors on the tumor cell surface, causing perturbation of HER2signaling and resulting in antiproliferative effects. ${ }^{2}$ Immune-related mechanisms result from engagement of fragment crystallizable (Fc) domains of tumor cell-bound antibodies with Fc receptors (FcRs) expressed by immune cells. FcRs mediate cross talk between innate and adaptive immune responses and display polymorphic variants that exhibit different activation properties (figure 1). ${ }^{3-8}$

\section{Fc $\gamma$ receptors}

FcRs are expressed on immune cells and bind the Fc portion of immunoglobulin. ${ }^{9} 10$ $\mathrm{Fc} \gamma$ receptors (Fc $\gamma \mathrm{Rs}$ ), the largest group of FcRs, bind IgG and comprise several subtypes (figure 2). ${ }^{9-33}$ Low-affinity Fc $\gamma$ Rs, with binding affinities ranging from $30 \mathrm{nM}$ to $1000 \mathrm{nM}$, are important mediators of antibody functions in vivo, including antibody-dependent cellular cytotoxicity (ADCC), antibody-dependent cellular phagocytosis (ADCP), and induction of cytokines and chemokines. ${ }^{11}$ Under physiologic conditions, low-affinity Fc $\gamma \mathrm{R}$ binding is a function of avidity that occurs via multimerization in immune complexes or by cell opsonization. ${ }^{11}$ Low-affinity Fc $\gamma$ Rs include two activating receptors, Fc $\gamma$ RIIIa (CD16A) and FcyRIIa (CD32A), as well as the sole inhibitory receptor, Fc $\gamma$ RIIb (CD32B). ${ }^{34}$ Activating 


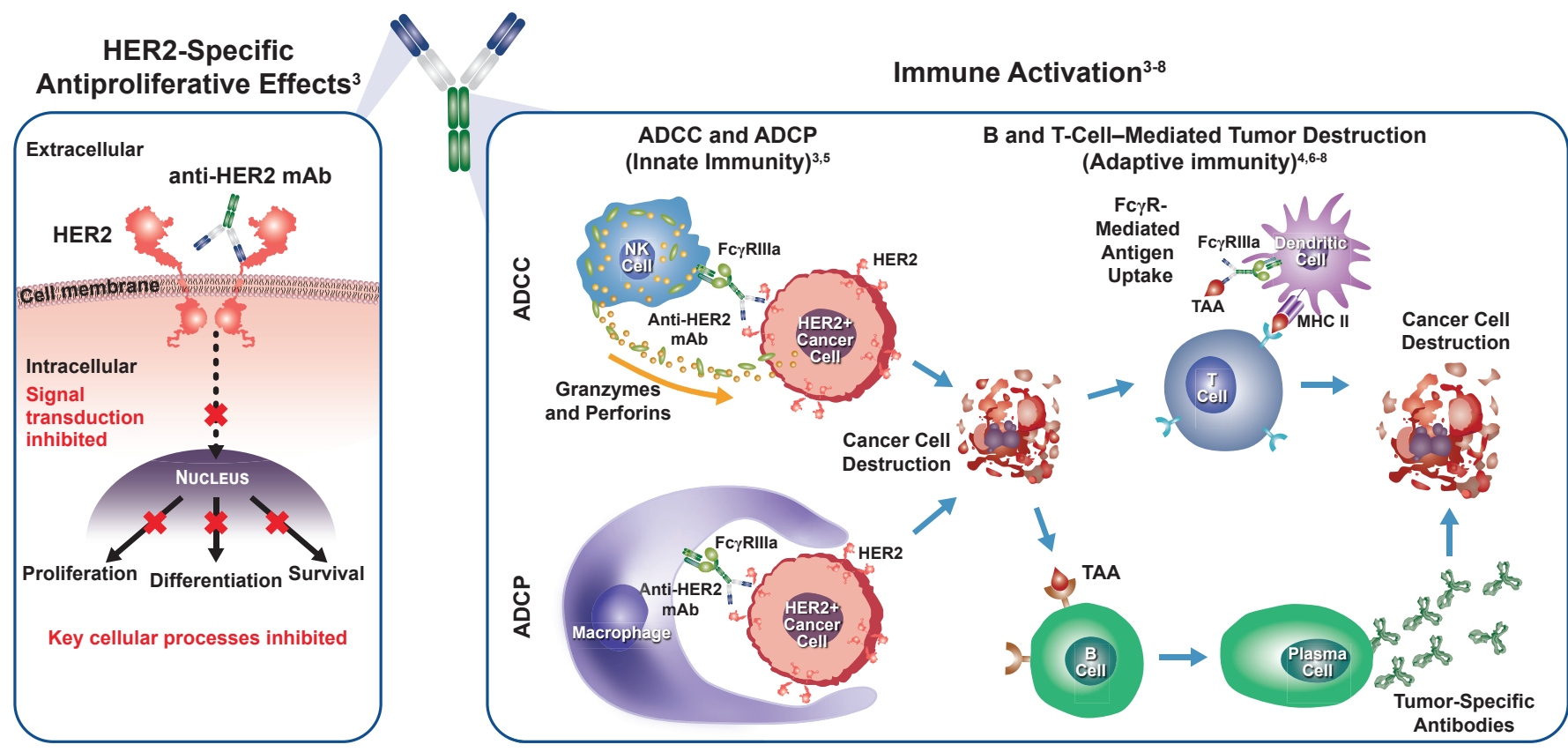

Figure 1 Mechanism of action of anti-HER2 mAbs: antiproliferative effects and immune activation. ADCC, antibody-dependent cellular cytotoxicity; ADCP, antibody-dependent cellular phagocytosis; Fc $\gamma R$, fragment crystallizable gamma receptor; HER2, human epidermal growth factor receptor 2; mAb, monoclonal antibody; MHC II, major histocompatibility complex class II; NK, natural killer; TAA, tumor-associated antigen. The red $\mathrm{X}$ in the left panel indicates inhibition.

Fc $\gamma$ Rs signal via their immunoreceptor tyrosine-based activation motifs. ${ }^{9}{ }^{34}$ The inhibitory Fc $\gamma \mathrm{R}$ contains an immunoreceptor tyrosine-based inhibition motif that counters cell activation when inhibitory and activating receptors become co-engaged. ${ }^{934}$

Monocytes, macrophages, and dendritic cells express both low-affinity activating Fc $\gamma$ Rs and the inhibitory Fc $\gamma \mathrm{R}$, with antibody-mediated activation of these innate immune cells influenced by the Fc $\gamma \mathrm{R}$ activating/inhibitory ratio. ${ }^{10}$ Monocytes, macrophages, and dendritic cells also express Fc $\gamma$ RI, a high-affinity receptor that binds monomeric uncomplexed IgG molecules. ${ }^{11}$ Fc $\gamma$ RI saturation by endogenous circulating IgGs in vivo may attenuate its role in mediating antibody function. ${ }^{35}$ Other circulating blood cells

\begin{tabular}{|c|c|c|c|c|c|c|}
\hline Name & $\begin{array}{l}\text { FcyRI } \\
\text { CD64 }\end{array}$ & $\begin{array}{l}\text { Fc } \gamma \text { RIIa } \\
\text { CD32A }\end{array}$ & $\begin{array}{l}\text { FcyRIIb } \\
\text { CD32B }\end{array}$ & $\begin{array}{l}\text { Fc } \gamma \text { RIlc } \\
\text { CD32C }\end{array}$ & $\begin{array}{c}\text { FcyRIIIa } \\
\text { CD16A }\end{array}$ & $\begin{array}{c}\text { FcyRIIIb } \\
\text { CD16B }\end{array}$ \\
\hline \multicolumn{7}{|l|}{ Structure $^{11}$} \\
\hline & Activating & Activating & Inhihitor & Astivating & Astivating & Activating \\
\hline Function $^{11}$ & Activating & Activanng & Innibitory & Activaning & Activanng & Activanng \\
\hline Affinity $^{11}$ & High & Low & Low & Low & Low & Low \\
\hline $\begin{array}{l}\text { Cell } \\
\text { Distribution } \\
\text { 9,12-26 }\end{array}$ & $\begin{array}{l}\text { Macrophages, monocytes, } \\
\text { neutrophils, dendritic cells, } \\
\text { mast cells }\end{array}$ & $\begin{array}{c}\text { Macrophages, monocytes, } \\
\text { neutrophils, eosinophils } \\
\text { basophils, dendritic cells, } \\
\text { mast cells }\end{array}$ & $\begin{array}{l}\text { Macrophages, monocytes, } \\
\text { eosinophils, basophils, } \\
\text { B cells, mast cells, } \\
\text { dendritic cells }{ }^{b}\end{array}$ & $\begin{array}{c}\text { NK cells, monocytes, } \\
\text { neutrophils, macrophages, } \\
\text { B cells }{ }^{\mathrm{c}}\end{array}$ & $\begin{array}{c}\text { NK cells, NKT cells, } \\
\gamma \delta \text { T cells, dendritic cells, } \\
\text { macrophages, monocytes, } \\
\text { neutrophils, eosinophils }\end{array}$ & $\begin{array}{l}\text { Neutrophils, eosinophils, } \\
\text { basophils }\end{array}$ \\
\hline $\begin{array}{l}\text { Effect of Antibody } \\
\text { Binding } \\
\text { (10,27-33 }\end{array}$ & $A D C P$, cytokine release & $\begin{array}{l}\text { ADCC, ADCP, } \\
\text { vaccinal effect }\end{array}$ & $\begin{array}{c}\text { Inhibits ADCC, ADCP, } \\
\text { B cell activation }\end{array}$ & $\begin{array}{c}\text { Enhances ADCC, ADCP, } \\
B \text { cell activation }\end{array}$ & $A D C C, A D C P$ & $\begin{array}{l}\text { Decoy receptor that } \\
\text { inhibits ADCPd }\end{array}$ \\
\hline
\end{tabular}

Figure 2 FcyRs differ in their function, cell distribution, immune response, signaling motifs, and affinity for lgG molecules. ${ }^{\mathrm{a}}$ Dendritic cells internalize $\mathrm{Ag}: \mathrm{Ab}$ immune complexes and present $\mathrm{Ag}$ to $\mathrm{T}$ cells. ${ }^{\mathrm{b}} \mathrm{CD} 32 \mathrm{~B}$ is expressed on NK cells in $\sim 3 \%$ of humans due to an FCGR2C-FCGR3B gene deletion that links the FCGR2C promoter to the FCGR2B coding sequence. ${ }^{\mathrm{C}} \mathrm{CD} 32 \mathrm{C}$ is expressed in $\sim 20 \%$ of humans due to an unequal crossover of FCGR2A and FCGR2B genes. ${ }^{\mathrm{d}} \mathrm{Same}$ ECD as CD16A but lacks intracellular signaling motifs. ADCC, antibody-dependent cellular cytotoxicity; ADCP, antibody-dependent cellular phagocytosis; ECD, extracellular domain; FçR, fragment crystallizable gamma receptor; GPI, glycophosphatidylinositol; ITAM, immunoreceptor tyrosine-based activation motif; ITIM, immunoreceptor tyrosine-based inhibition motif; NK, natural killer; NKT, natural killer T cell. 
generally express more limited repertoires of Fc $\gamma$ Rs. ${ }^{11} 36$ Natural killer (NK) cells mainly express Fc $\gamma$ RIIIa. ${ }^{11}{ }^{36} \mathrm{NK}$ cells and monocytes may also express Fc $\gamma$ RIIc (CD32C); however, the gene for this receptor is polymorphic at a site that determines a premature stop codon in one of its exons; hence, translation yields a functional activating Fc $\gamma$ R in only a minority $(\sim 20 \%)$ of humans. ${ }^{17}{ }^{22}$ An even smaller subset $(\sim 3 \%)$ of humans have NK cells that also express FcyRIIb, the inhibitory receptor, due to a chromosomal deletion that juxtaposes the promoter of the gene for Fc $\gamma$ RIIc with the coding sequences for Fc $\gamma$ RIIb. ${ }^{16}{ }^{37}$ Neutrophils express high levels of Fc $\gamma \mathrm{RIIIb}$ (CD16B), a glycosylphosphatidylinositol-linked receptor that lacks intracellular signaling motifs and likely serves as a decoy receptor. ${ }^{32}$ Neutrophils

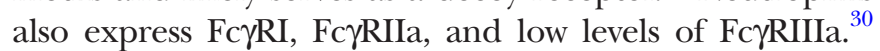
Platelets express Fc $\gamma$ RIIa. ${ }^{38} \mathrm{~B}$ cells mainly express inhibitory receptor Fc $\gamma \mathrm{RIIb},{ }^{11}$ where it counters activation mediated by the B cell receptor. B cells may also express Fc $\gamma$ RIIc, but only in a minority $(20 \%)$ of humans. ${ }^{27}{ }^{36}$ While naive $\mathrm{T}$ cells do not express Fc $\gamma R s$, subsets of activated CD4+ T cells may express Fc $\gamma$ RIIIa, Fc $\gamma$ RIIa, and Fc $\gamma$ RIIb, ${ }^{39} 40$ and subsets of activated memory CD8+ T cells may express Fc $\gamma$ RIIb. ${ }^{41}$ CD56+ (neural cell adhesion molecule) subsets of CD3+ T cells express Fc $\gamma$ Rs and are capable of mediating ADCC, such as NK T cells expressing Fc $\gamma$ RIIIa and $\gamma \delta$ T cells expressing Fc $\gamma$ RIIa and Fc $\gamma$ RIIIa. ${ }^{24}$ These small subsets of FcyR-expressing $\mathrm{T}$ cells potentially could influence the linkage between innate and adaptive immunity. Inhibitory receptor Fc $\gamma \mathrm{RIIb}$ is also expressed at high levels in nonimmune cells, such as endothelial and some stromal cells, where it functions as a scavenger receptor and mediates clearance of small immune complexes. ${ }^{42}$

\section{Fc $\gamma R$ polymorphisms}

Numerous polymorphisms and allelic variations have been identified for Fc $\gamma$ Rs. ${ }^{1043}$ Fc $\gamma$ RIIa and Fc $\gamma$ RIIIa allelic polymorphisms generate variants that bind to IgG Fc with different affinities correlating with relative ADCC potency. Fc $\gamma$ RIIa 131H (histidine) and Fc $\gamma$ RIIIa 158V (valine) have a higher affinity for IgG Fc, compared with

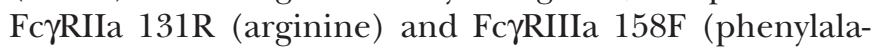
nine), respectively. Fc $\gamma$ RIIb allelic polymorphism generates variants with altered signaling function. The Fc $\gamma$ RIIb 232T (threonine) signaling variant is unable to associate with lipid rafts, resulting in impaired negative regulatory activity compared with FcyRIIb 232I (isoleucine). Prevalence of these polymorphisms in the general population, including healthy subjects and patients with cancer, is provided in table 1 and online supplemental table $1 .^{44-73}$ Fc $\gamma$ RIIIa-158V homozygotes represent $~ 12 \%$ of the population, across race. ${ }^{44-64}$ Fc $\gamma$ RIIa-131H homozygotes represent $\sim 27 \%$ of Caucasians and Blacks 44454950 54-56 58 65-67 versus $\sim 60 \%$ of Asians. ${ }^{48596062}$ Fc $\gamma$ RIIb-232T homozygotes represent $\sim 2 \%$ of Caucasians ${ }^{5456586-70}$ and $\sim 6 \%$ of Asians or Blacks. ${ }^{48} 6870-73$

\section{ADCC mediated by therapeutic mAbs}

ADCC is an Fc-dependent mechanism mediated by innate immune cells. ${ }^{1136}$ ADCC by NK cells is mediated through its Fc $\gamma$ RIIIa receptors, ${ }^{28} 74$ which bind Fc regions of tumorbound antibodies to form immunological synapses, triggering secretion of perforins and granzymes that induce tumor cell death (figure 3). ${ }^{75}$ Five different granzymes have been described in humans: A, B, H, K, and M. Granzyme $\mathrm{B}$ induces caspase-dependent apoptosis, whereas granzymes $\mathrm{A}, \mathrm{H}, \mathrm{K}$, and $\mathrm{M}$ induce caspase-independent cell death. ${ }^{75} 76$

Diverse therapeutic mAbs, targeting CD20, HER2, and epidermal growth factor receptor, are capable of mediating ADCC to eliminate cancer cells. ${ }^{77}$ Correspondingly, rituximab, ofatumumab, veltuzumab, ocrelizumab, trastuzumab, and cetuximab have demonstrated ADCC activity mediated by human peripheral blood mononuclear cells (PBMCs) or NK cells in vitro. ${ }^{37-79}$ ADCC stimulation

Table 1 Prevalence of polymorphic variants of Fc $\gamma R$ IIIa, Fc $\gamma R$ Ila, and Fc $\gamma R$ Illb, based on available literature

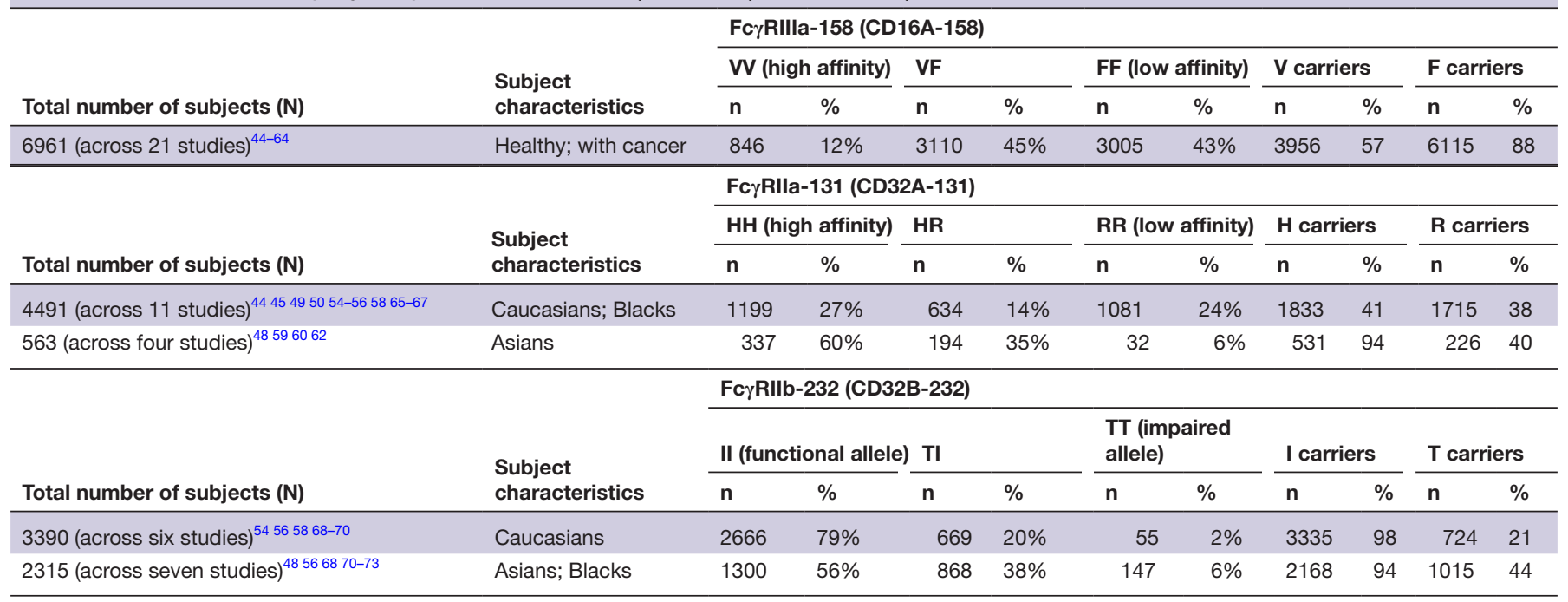

Fc $\gamma \mathrm{R}$, fragment crystallizable gamma receptor. 


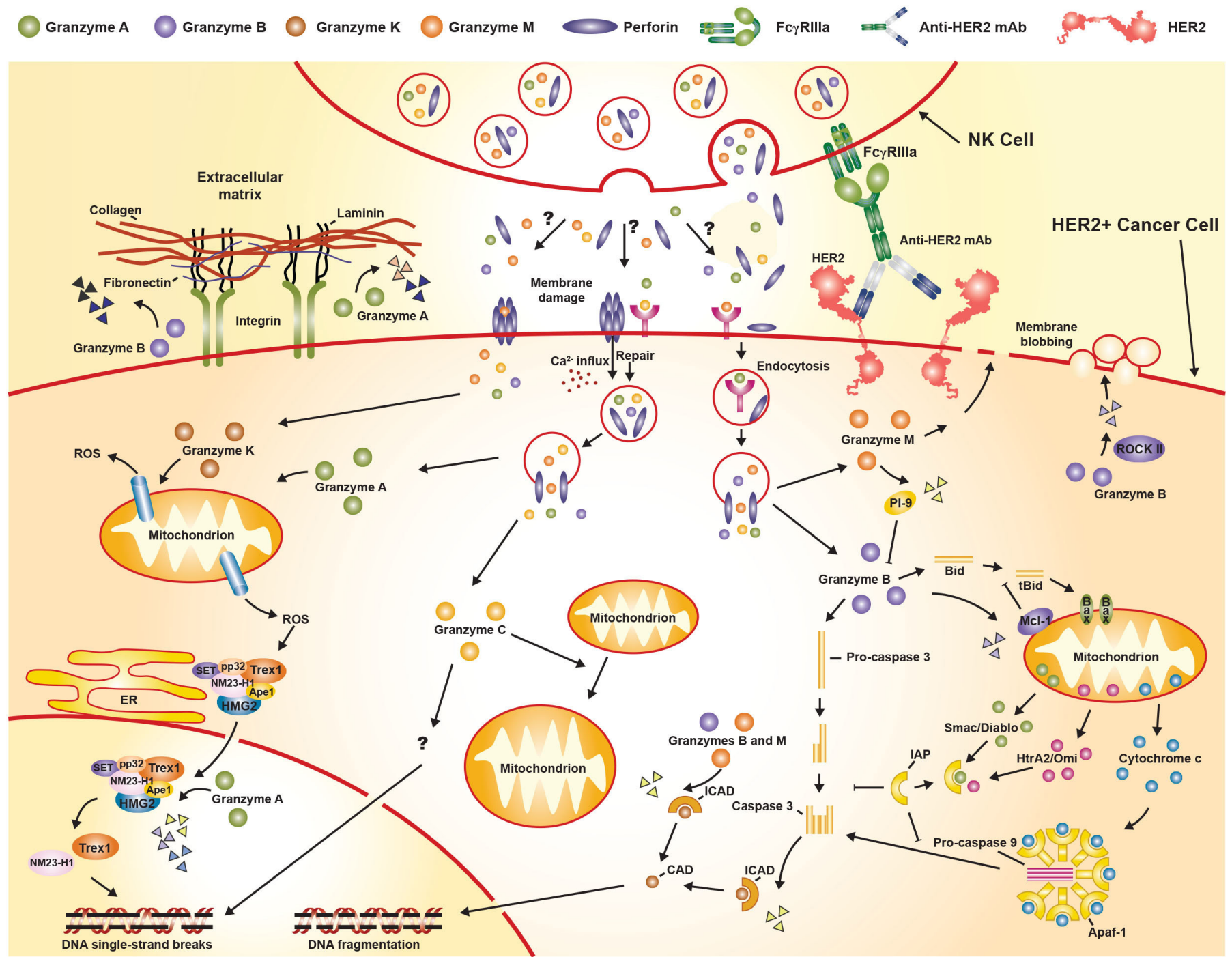

Figure 3 Classical granzyme/perforin-mediated apoptosis pathway (adapted from Bots and Medema ${ }^{76}$ ). Bid, BH3 interacting domain death agonist; CAD, caspase-activated DNase; ER, endoplasmic reticulum; Fc $\gamma R$, fragment crystallizable gamma receptor; HER2, human epidermal growth factor receptor 2; HMG2, high-mobility group protein 2; ICAD, inhibitor of caspaseactivated DNase; mAb, monoclonal antibody; Mcl-1, myeloid-cell leukemia 1; NK, natural killer; PI-9, proteinase inhibitor 9; ROS, reactive oxygen species; tBid, truncated Bid.

by trastuzumab against HER2+ breast cancer cells was demonstrated in ex vivo assays using human PBMCs or NK cells from patients with HER2+ breast cancer treated with trastuzumab. ${ }^{80}$ Subsequently, Fc $\gamma \mathrm{R}$ knockout mouse models demonstrated that activating Fc $\gamma$ Rs mediate in vivo antitumor activity of therapeutic antibodies such as trastuzumab or rituximab, whereas FcyRIIb inhibits in vivo antitumor activity. ${ }^{77}$ Trastuzumab Fc domain mutants engineered to disrupt Fc $\gamma \mathrm{R}$ binding also attenuate antitumor effects in vivo. ${ }^{77}$ Interestingly, in vitro ADCC assays confirm that the HER2-directed antibody drug conjugate ado-trastuzumab emtansine (T-DM1) maintains ADCC activity of trastuzumab, which potentially may supplement the antitumor activity mediated by its cytotoxic payload. ${ }^{81}$

Pertuzumab binds independently (ie, without competing with trastuzumab) to a distinct epitope on HER2, which overlaps the dimerization domain; however, it carries the same wild-type IgG1 Fc domain as trastuzumab. ${ }^{8283}$ Pertuzumab is more effective than trastuzumab in inhibiting HER2 dimer formation with other HER family members, such as HER3 or HER $1 .^{83}$ Both pertuzumab and trastuzumab can trigger ADCC. ${ }^{83}$ It is postulated that simultaneous binding of trastuzumab and pertuzumab to HER2 enhances the density of Fc $\gamma \mathrm{R}$ binding sites on HER2+ tumor cells, increasing the possibility for NK cell-mediated ADCC and macrophagemediated ADCP antitumor responses. ${ }^{74}$ When the antibodies were combined, a modest additive effect on ADCC was reported ${ }^{83}$ However, the combination of trastuzumab and pertuzumab exhibited strongly enhanced antitumor activity in nude mice bearing HER2-overexpressing human KPL- 4 breast cancer xenografts, which appears to be solely attributed to Fc-dependent effects because KPL-4 cells are resistant to the direct, antiproliferative effects of trastuzumab or pertuzumab. ${ }^{83}$ In the metastatic (CLEOPATRA) ${ }^{84}$ and neoadjuvant (NeoSphere) ${ }^{85}$ settings of HER2+ breast cancer, significantly improved responses were observed 
when trastuzumab and pertuzumab were combined. In CLEOPATRA, the end-of-study result for median OS was 57.1 months (95\% CI 50 to 72) for trastuzumab + pertuzumab + docetaxel compared with 40.8 months $(95 \%$ CI 36 to 48 ) for trastuzumab + docetaxel (HR 0.69; $95 \%$ CI 0.58 to 0.82). ${ }^{84}$ In NeoSphere, the 5-year DFS result was $84 \%(95 \%$ CI $72 \%$ to $91 \%$ ) for trastuzumab + pertuzumab + docetaxel compared with $81 \%$ (95\% CI $72 \%$ to $88 \%$ ) for pertuzumab + docetaxel (HR $0.60 ; 95 \%$ CI 0.28 to 1.27 ) ${ }^{85}$

Improved clinical responses are observed when trastuzumab or trastuzumab + pertuzumab therapy is combined with taxane-based chemotherapy. ${ }^{25}$ Taxanes are microtubule assembly inhibitors that disrupt cell division, but they can also exert effects on the immune system by inducing immunogenic cell death and triggering immunostimulatory stress responses. ${ }^{86}$ For example, trastuzumab + taxane treatment of patients with HER2+ breast cancer has been shown to increase NKG2D expression on circulating NK cells and enhance trastuzumab-mediated ADCG measured ex vivo. ${ }^{87}$ NKG2D is a key receptor for NK cell activation that recognizes ligands (MHC class I chain-related A or B (MICA or MICB) proteins or UL-16 binding proteins), which can be induced on breast tumor cells after taxane treatment.

Immunoglobulin Fc region glycosylation can significantly affect receptor binding and ADCC activity. Hence, robust quality management systems are important to ensure process and product consistency when manufacturing such mAbs and their biosimilars. ${ }^{88}$ High levels of fucosylated glycans in the Fc region of some trastuzumab lots were found to be associated with reduced binding of trastuzumab's Fc region to Fc $\gamma$ RIIIa, which led to decreased ADCC activity. ${ }^{88}$ These commercial reference lots of originator trastuzumab were used in the control arm of the phase III neoadjuvant trial of the Samsung trastuzumab biosimilar SB3 in patients with HER2+ early breast cancer. ${ }^{89}$ Higher event-free survival rates in the SB3 versus control arm were attributed to altered lots of trastuzumab used in the trial, underscoring the importance of Fc-dependent mechanisms, including ADCC, in clinical outcome ${ }^{89}$ High levels of Fc region mannose glycans observed in other lots of trastuzumab were found to cause increased binding of trastuzumab Fc to Fc $\gamma$ RIIIa, which led to an increase in ADCC activity. ${ }^{88}$

Fc-mediated activities of the antibody-drug conjugates (ADC) T-DM1, DS-8201a (or fam-trastuzumab deruxtecan-nxki), and SYD985 (or vic-trastuzumab duocarmazine), do not appear to be altered compared with the unconjugated parental antibody, since in vitro ADCC mediated by these ADCs was comparable to unconjugated trastuzumab. ${ }^{819091}$

\section{Strategies to enhance ADCC activity of therapeutic mAbs}

Diverse mAbs targeting various antigens have been developed using Fc glyco-engineering or Fc protein-engineering. ${ }^{92}$ Antibody Fc glyco-engineering specifically improves Fc $\gamma$ RIIIa binding affinity, which can enhance ADCC. ${ }^{93} 94$ As an example, obinutuzumab is a CD20-directed $\mathrm{mAb}$ that binds to a distinct but overlapping epitope compared with rituximab and has an afucosylated Fc domain that allows ADCC to be mediated more effectively in vitro than rituximab; ${ }^{93}$ obinutuzumab is approved for treatment of patients with chronic lymphocytic leukemia or follicular lymphoma. Compared with trastuzumab, afucosylated trastuzumab enhanced ADCC mediated by human NK cells in vitro, delayed tumor progression in xenograft models of HER2-amplified breast cancer in immune-deficient mice transgenic for human Fc $\gamma$ RIIIa-158F (the weaker binding variant), and improved antitumor responses in patients with solid tumors. ${ }^{9596}$

Fc protein-engineering represents another strategy to enhance ADCC activity. For example, margetuximab, approved for HER2+ metastatic breast cancer (MBC), is an Fc-engineered anti-HER2 $\mathrm{mAb}$ that targets the same epitope as trastuzumab. ${ }^{97}$ Five amino acid substitutions in the IgG1 Fc domain (L235V/F243L/R292P/ $\mathrm{Y} 300 \mathrm{~L} / \mathrm{P} 396 \mathrm{~L})$ led to increased binding to activating FcyRIIIa, but also decreased binding to inhibitory Fc $\gamma$ RIIb. ${ }^{97}$ Margetuximab mediated enhanced ADCC in vitro compared with trastuzumab. In a xenograft model of HER2-amplified breast cancer in immune-deficient mice transgenic for human Fc $\gamma$ RIIIa-158F, margetuximab exhibited greater antitumor activity than an otherwise identical variant with a wild-type IgG1 Fc domain. ${ }^{97} 98$

Editing of the glycocalyx, a thick coat of proteins and carbohydrates on the outer surface of tumor cells, with an antibody-enzyme conjugate that selectively removes sialic acids also improves ADCC. ${ }^{99}$ A trastuzumabsialidase conjugate desialylated tumor cells in an HER2dependent manner and this led to enhanced ADCC in vitro. ${ }^{99}$ Another approach to enhance ADCC is combination therapy; for example, treatment with trastuzumab and lapatinib increased ADCC in vitro by stabilizing the display of cell surface HER2. ${ }^{55100} 101$ Lastly, a bispecific tribody ([HER2 $\left.]_{2} \times \mathrm{CD} 16\right)$ that comprises two HER2specific single chain fragment variable domains fused to a Fab specific for the extracellular domain of Fc $\gamma R I I I a$ was shown to mediate in vitro ADCC of HER2-expressing tumor cells more efficiently than trastuzumab. ${ }^{102}$

\section{ADCP mediated by therapeutic mAbs}

ADCP, which is mediated by phagocytic cells such as macrophages, monocytes, or neutrophils, is another important Fc-mediated mechanism of action of antibodies that target HER2+ tumors. Macrophages express all classes of Fc $\gamma$ Rs. Tumor-associated macrophages (TAM) from primary human breast tumors have been shown to promote tumor progression, and increased TAM infiltration often correlates with poor progression. ${ }^{103}$ Nevertheless, TAMs express elevated levels of activating receptors Fc $\gamma$ RIIa and Fc $\gamma$ RIIIa and retain the ability to phagocytose tumor cells in an antibody-dependent manner. ${ }^{104}$ In vitro studies of trastuzumab-mediated ADCP of HER2-overexpressing tumor cells demonstrate that FcyRIIIA has greater influence than FcyRIIa. ${ }^{105}$ Breast cancer xenograft studies in mice, in which macrophages are depleted by treatment 
with clodronate liposomes, demonstrate that the antitumor activity of trastuzumab depends on macrophage recruitment in the tumor tissues. ${ }^{21}$ Combination of trastuzumab and pertuzumab, presumably owing to increased avidity of binding to macrophage FcyRs, elevates ADCP potency in vitro compared with the individual antibodies. ${ }^{105}$

\section{Strategies to enhance ADCP}

The glyco-engineered Fc version of trastuzumab with enhanced FcyRIIIa binding affinity mediates ADCP in vitro better than wild-type trastuzumab. ${ }^{106}$ Variants with Fc domains engineered for increased affinity for activating Fc $\gamma$ RIIa have enhanced ability to mediate ADCP but surprisingly, variants with altered binding affinity to inhibitory FcyRIIb have little effect on ADCP. ${ }^{107}$ CD47 is an antiphagocytic 'don't eat me' signal that is highly expressed in many cancers, including breast cancer, which functions to suppress phagocytosis through binding to and triggering signaling of macrophage SIRP $\alpha .{ }^{108}$ Combination of trastuzumab and a CD47-blocking antibody (MIAP410) enhanced ADCP in vitro, and in immunocompetent mice bearing HER2+ tumors, the combination improved antitumor responses and prolonged survival due to expansion and activation of TAMs and emergence of a hyperphagocytic macrophage population. ${ }^{109}$ In another study, combination of trastuzumab with an anti-CD47 mAb (magrolimab: Hu5F9-G4) enhanced ADCP in vitro and improved inhibition of HER2+ xenograft growth in vivo, such that inhibition of tumor growth persisted even after treatment discontinuation. Significantly increased susceptibility to ADCP was also observed in vitro against HER2+ breast cancer cell lines selected for tolerance to trastuzumab-mediated ADCC (yet retained cell surface HER2 expression levels). ${ }^{110}$ It will be interesting to discover whether margetuximab may further enforce ADCP mechanisms with magrolimab, as compared with trastuzumab. Future clinical translation of combinatorial therapeutic approaches targeting HER2 and $\mathrm{CD} 47$ are warranted. Other promising approaches to improve ADCP against HER2-overexpressing tumor cells include combining trastuzumab with $\mathrm{B} 7-\mathrm{H} 4$ blockade $^{111}$ or combining trastuzumab with a histone deacetylase inhibitor, such as vorinostat or valproic acid. ${ }^{112}$

\section{Fc $\gamma R$ polymorphisms are associated with the clinical outcome of HER2+ breast cancer after trastuzumab in the neoadjuvant, adjuvant, and metastatic settings}

Fc $\gamma$ RIIIa and Fc $\gamma$ RIIa polymorphism effects on breast cancer clinical outcomes have been studied in multiple settings (table 2).

The neoadjuvant randomized phase II CHER-LOB trial evaluated preoperative chemotherapy plus trastuzumab (Arm A) or lapatinib (Arm B) or trastuzumab and lapatinib (Arm C) in 121 patients with operable HER2+ breast cancer. ${ }^{55}$ Combined chemotherapy plus trastuzumab and lapatinib (Arm C) provided a statistically significant improvement in pathologic complete response (pCR) rate in the whole-study population. ${ }^{55}$
Efficacy analysis by Fc $\gamma$ RIIIa-158 genotype in 73 patients from the CHER-LOB study showed that pCR rate improvement on chemotherapy plus trastuzumab and lapatinib was restricted to Fc $\gamma$ RIIIa-158V carriers (pCR rate in Arm C vs A: $67 \%$ vs 27\%, $\mathrm{p}=0.043$; Arm C vs B: $67 \%$ vs $22 \%, \mathrm{p}=0.012$ ). By contrast, Fc $\gamma$ RIIIa$158 \mathrm{~F}$ homozygotes had no significant improvement in pCR rate on chemotherapy plus trastuzumab and lapatinib ( $\mathrm{pCR}$ rate in Arm C vs A: $42 \%$ vs $25 \%, \mathrm{p}=0.642$; Arm C vs B: $42 \%$ vs $50 \%, \mathrm{p}=0.737) .{ }^{55}$ Separately, a small prospective study with 15 patients with early stage HER2+ breast cancer showed that Fc $\gamma$ RIIa-131H homozygotes had higher pCR on trastuzumab-based neoadjuvant chemotherapy $(71 \%(5 / 7))$, compared with Fc $\gamma$ RIIa-131R carriers $(0 \%(0 / 8) ; \mathrm{p}=0.015) .{ }^{59}$ Another small prospective study with 26 patients with HER2+ ductal breast cancer treated with trastuzumab-based neoadjuvant chemotherapy, found that among the 12 patients who achieved pCR, half were Fc $\gamma$ RIIa-131R homozygotes $(50 \%(6 / 12))$, while the other half were either Fc $\gamma$ RIIa-131H homozygotes $(25 \%(3 / 12))$ or Fc $\gamma$ RIIa-131H/R heterozygotes (25\% (3/12)), showing a statistically significant association between Fc $\gamma$ RIIa131R homozygous genotype and pCR $(p=0.012) .{ }^{113}$ No association was detected for the Fc $\gamma$ RIIIa-158 polymorphism $(\mathrm{p}=0.590) .{ }^{113}$

The adjuvant randomized phase III NSABP B-31 trial demonstrated that addition of trastuzumab to postoperative chemotherapy improves outcomes after surgically resected HER2+ breast cancer. ${ }^{114}$ Retrospective analysis of 1156 patients from this study found that adjuvant chemotherapy plus trastuzumab provided greater DFS benefit in FcyRIIIa-158V carriers (HR 0.31; 95\% CI 0.22 to 0.43; $\mathrm{p}<0.001$ ), compared with Fc $\gamma$ RIIIa-158F homozygotes (HR $0.71 ; 95 \%$ CI 0.51 to $1.01 ; p=0.05) .{ }^{45}$ Of note, large retrospective analyses of over 1000 patients enrolled in the phase III BCIRG-006 trial or the phase III NCCTG-N9831 study found no correlation between Fc $\gamma$ RIIIa or Fc $\gamma$ RIIa polymorphisms and outcome (DFS) with adjuvant trastuzumab in early breast cancer. ${ }^{46} 56$ The analysis on patients from the NCCTG-N9831 trial found a statistically significant treatment interaction between the Fc $\gamma \mathrm{RIIb}$ polymorphism (I/I vs $\mathrm{T}$ carriers) and treatment arms $(\mathrm{p}=0.03)$, with Fc $\gamma \mathrm{RIIb}$ 232I homozygotes treated with adjuvant trastuzumab having a better DFS than those treated with chemotherapy alone $(\mathrm{p}<0.0001) .{ }^{56}$ Both studies had sampling biases that may have reduced power to detect genotype-treatment interaction. In BCIRG-006, the subset of genotyped patients did not show significant benefit from trastuzumab, unlike the effect seen in the overall BCIRG-006 population. Also, Fc $\gamma$ RIIIa-158 genotype frequencies significantly deviated from Hardy-Weinberg equilibrium. By contrast, genotyped patients in the NCCTG-N9831 study had substantially better DFS than the entire NCCTG-N9831 population. A subgroup analysis conducted on 132 patients enrolled in the phase III UNICANCER-PACS04 trial treated with adjuvant chemotherapy followed by trastuzumab found that Fc $\gamma$ RIIa-131H carriers had a significantly higher 5-year event-free survival 


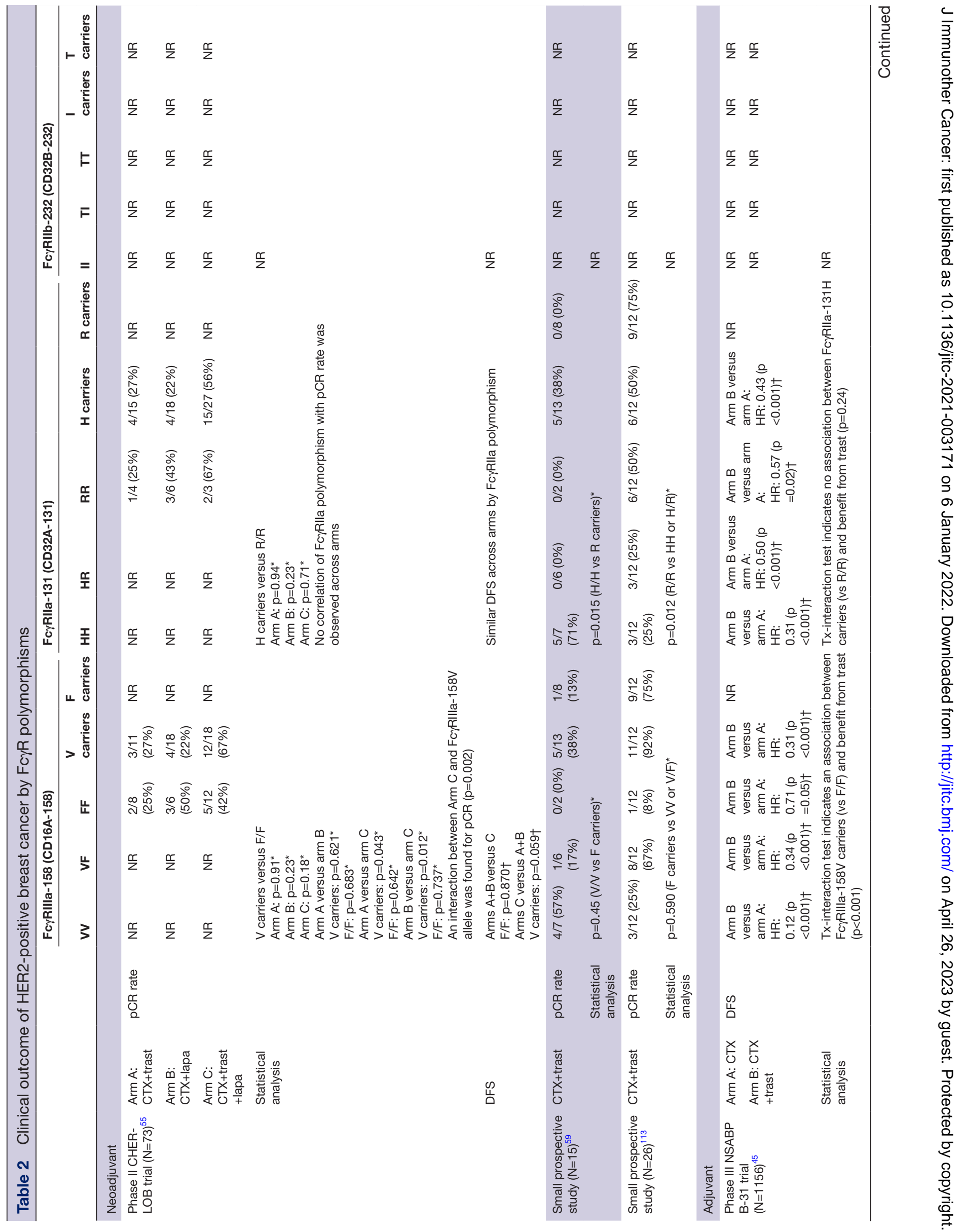




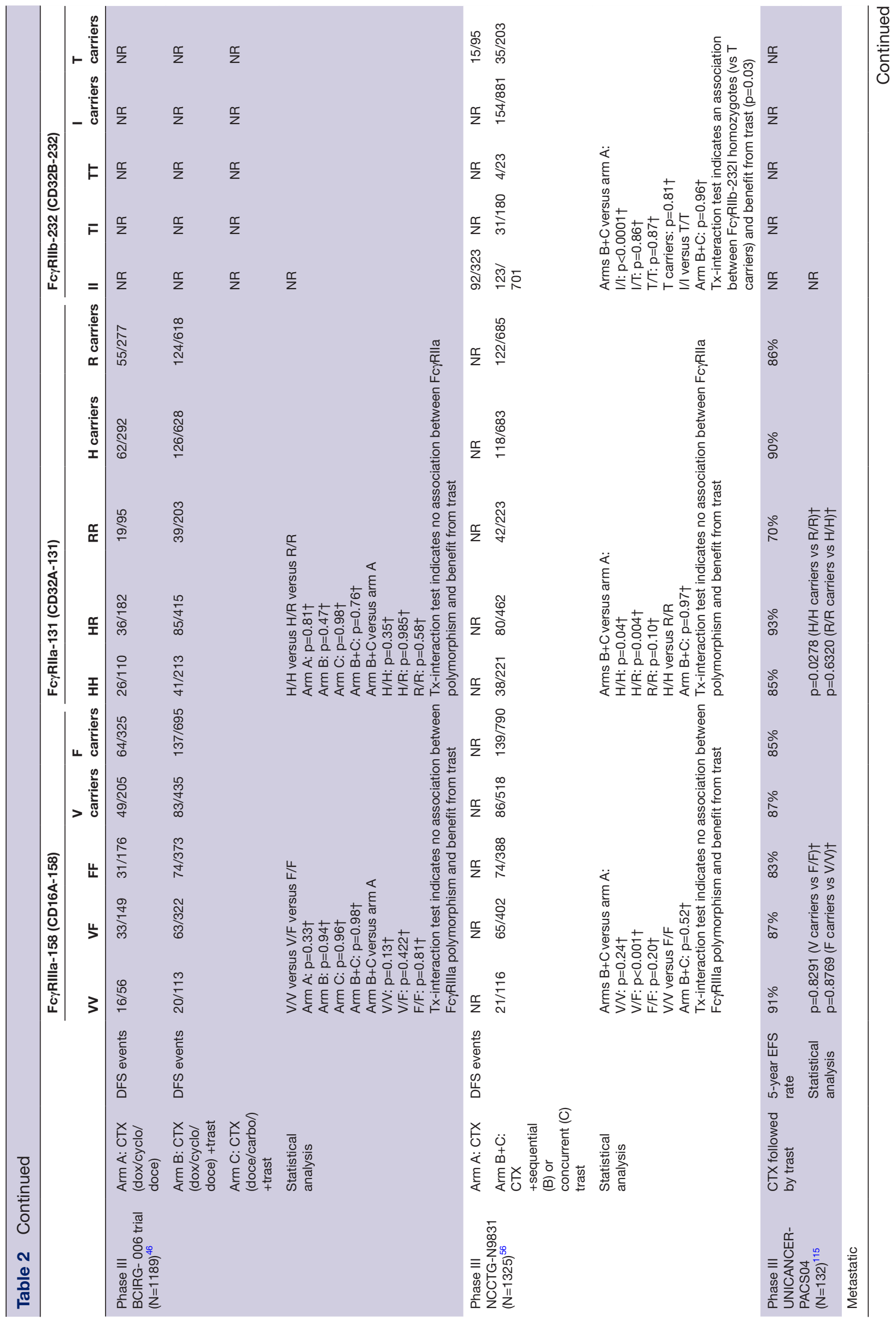




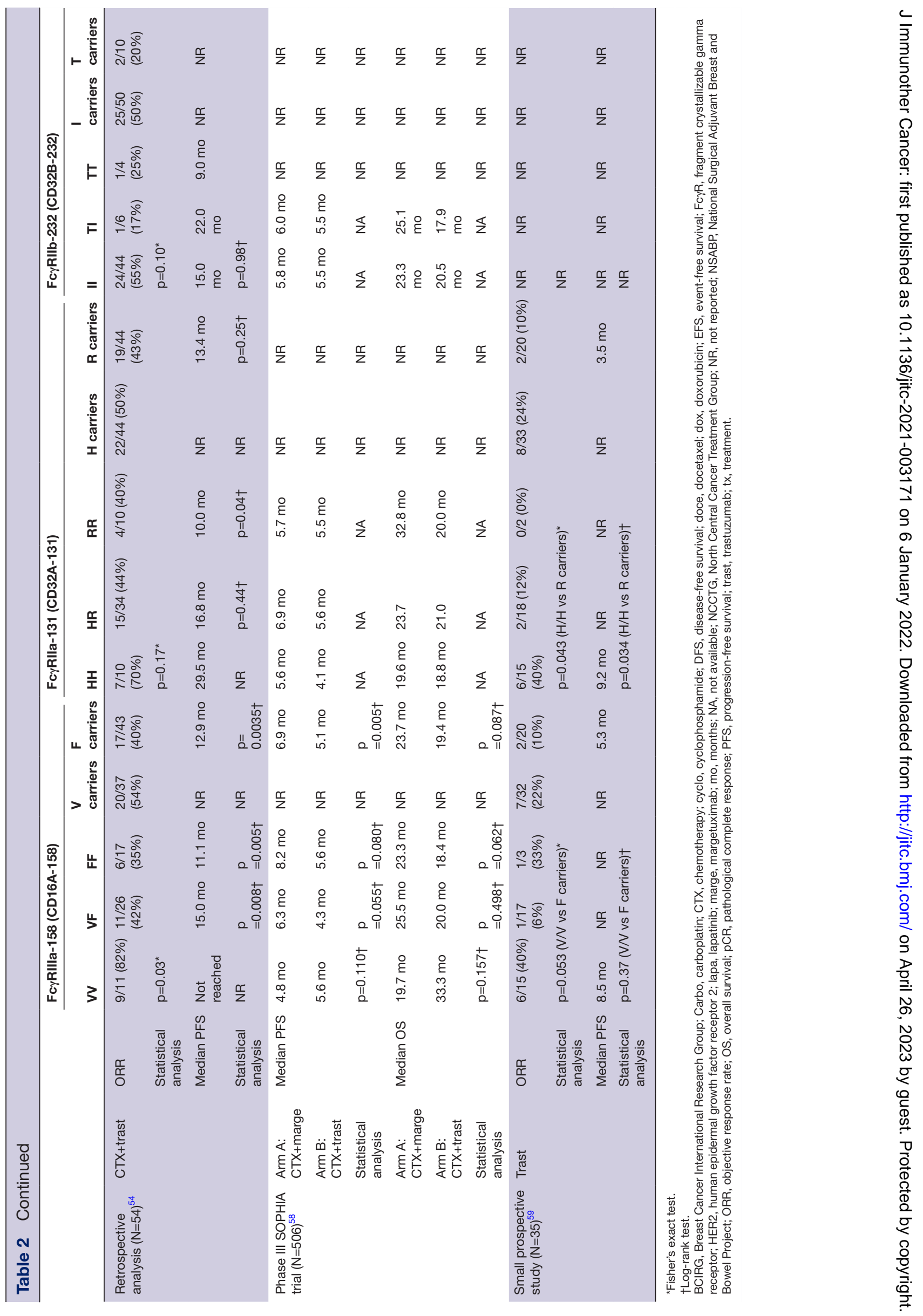


rate $(90 \%)$, compared with Fc $\gamma \mathrm{RIIa}-131 \mathrm{H}$ homozygotes (70\%; $\mathrm{p}=0.0278)$; whereas, clinical outcome was not associated with Fc $\gamma$ RIIIa-158 polymorphism. ${ }^{115}$

A retrospective analysis of 54 patients with HER2+ MBC receiving trastuzumab plus taxane revealed that Fc $\gamma$ RIIIa$158 \mathrm{~V}$ homozygotes experienced an improvement in PFS, objective response rate (ORR), and ex vivo ADCC activity, compared with Fc $\gamma$ RIIIa-158F carriers (median PFS: V/V-not reached, $F$ carriers -12.9 months $(\mathrm{p}=0.0035), \mathrm{F} / \mathrm{V}-15.0$ months $(\mathrm{p}=0.008), \mathrm{F} / \mathrm{F}-11.1$ months $(\mathrm{p}=0.005)$; ORR: $\mathrm{V} / \mathrm{V}-82 \%, \mathrm{~F}$ carriers $-40 \%$, $\mathrm{F} / \mathrm{V}-42 \%, \mathrm{~F} / \mathrm{F}-35 \%, \mathrm{p}=0.03$; normalized ADCC: $\mathrm{V} / \mathrm{V}$ vs F carrier, $\mathrm{p}=0.04) .{ }^{54}$ Finally, the randomized phase III SOPHIA trial (NCT02492711) investigated margetuximab versus trastuzumab, each combined with physician's choice chemotherapy in 536 patients with MBC after at least two prior anti-HER2 therapies. In SOPHIA, treatment with margetuximab and chemotherapy improved independently assessed PFS over control in the wholestudy population. ${ }^{58}$ Efficacy analysis by Fc $\gamma$ RIIIa- 158 allele expression in 506 genotyped patients from the SOPHIA study showed that PFS benefit of margetuximab over trastuzumab was increased in Fc $\gamma$ RIIIa-158F carriers (median PFS: 6.9 months vs 5.1 months; HR 0.68 ; $95 \%$ CI 0.52 to $0.90 ; \mathrm{p}=0.005){ }^{58}$ Conversely, no margetuximab benefit over trastuzumab was seen in Fc $\gamma$ RIIIa-158V homozygotes (HR $1.78 ; 95 \%$ CI 0.87 to $3.62 ; \mathrm{p}=0.110) .{ }^{58}$ In the SOPHIA trial, no association of Fc $\gamma$ RIIa-131 genotypes with benefit was observed for margetuximab, whose engineering did not increase binding to FcyRIIa. ${ }^{58}$ Of note, there also was no association between margetuximab benefit and Fc $\gamma$ RIIb-232 genotypes; however, this signaling polymorphism does not affect IgG1 Fc binding, with margetuximab demonstrating reduced binding to either variant. ${ }^{58}$ Importantly, Fc domain engineering to enhance immune effector function was shown to be clinically feasible in SOPHIA. Based on a recent press release, the SOPHIA final OS analysis for the intent-to-treat population did not demonstrate a statistically significant advantage in the margetuximab group compared with the trastuzumab group, while a numerical OS advantage was observed in the subgroup of patients homozygous for the FcyRIIIa$158 \mathrm{~F}$ low-affinity allele. In this trial, similar safety profiles between the margetuximab and trastuzumab treatment groups were observed, with infusion-related reactions more common in the margetuximab group. ${ }^{58}$ Finally, in the SOPHIA safety database, the adverse event 'left ventricular cardiac dysfunction' (all instances of which were asymptomatic and reversible) occurred in seven patients $(3 \%)$ in each treatment group. ${ }^{58}$

Fc $\gamma$ RIIa gene polymorphisms show more limited influence on outcomes, relative to Fc $\gamma$ RIIIa. In a small prospective study of 35 patients with HER2+ MBC treated with trastuzumab, Fc $\gamma$ RIIa-131H homozygotes experienced higher ORR and longer PFS compared with FcyRIIa131R carriers (ORR: $\mathrm{H} / \mathrm{H}-40 \%$, R carriers-10\%, $\mathrm{p}=0.043$, Fisher's exact test; median PFS: 9.2 months vs
3.5 months, $\mathrm{p}=0.034) .{ }^{59}$ Similarly, Fc $\gamma \mathrm{RIIa}-131 \mathrm{H}$ homozygotes had superior PFS compared with Fc $\gamma$ RIIa-131R carriers (HR $0.36 ; 95 \%$ CI 0.16 to $0.82 ; \mathrm{p}=0.02$ ) in a retrospective analysis conducted on 42 patients with metastatic gastric cancer (GC) treated with trastuzumab and chemotherapy. ${ }^{62}$

Fc $\gamma$ RIIIa polymorphism effects on clinical outcomes are also seen in other mAb-treated cancers. Rituximab and cetuximab have been assessed across studies in lymphoma and chronic lymphocytic leukemia (rituximab), colorectal cancer, and head and neck cancers (cetuximab). ${ }^{116}$ Analyses of rituximab studies did not show statistically different PFS based on Fc $\gamma \mathrm{R}$ genotype, and analyses of cetuximab studies were inconsistent. ${ }^{116}$

Association of $\mathrm{F} c \gamma \mathrm{R}$ genotypes with the clinical activity of immunomodulatory antibodies that target molecules expressed by immune cells also has been investigated, although studies in patients with breast cancer have not been reported in the literature yet. Antibodies targeting programmed cell death protein 1 (PD-1) are most commonly IgG4 isotype or IgG1 isotype engineered for debilitated Fc $\gamma \mathrm{R}$ binding; these Fc domains are selected for their minimal interaction with FcyRs to focus the antibody effects on blocking PD-1 binding to its ligands, programmed cell death ligand 1 (PD-L1) and PD-L2, and avoiding Fc-mediated deletion of tumor-reactive PD-1expressing T cells. ${ }^{117}$ Indeed, anti-PD-1 mAbs with IgG1 isotype are substantially less effective than those with IgG4 isotype. ${ }^{118}$ Thus, Fc $\gamma \mathrm{R}$ genotypes are irrelevant for anti-PD-1 mAbs, which is supported by the lack of association between Fc $\gamma$ RIIIa polymorphism in patients with advanced melanoma treated with pembrolizumab or nivolumab, both of which are IgG4 isotype. ${ }^{119}$ By contrast, the activity of anti-PD-L1 mAbs may be enhanced by the IgG1 isotype. Studies in mouse models demonstrated that antitumor activity mediated by PD-L1 mAbs was enhanced by engagement of activating Fc $\gamma$ Rs and that this effect correlated with elimination of monocytes and modulation of myeloid cells within the tumor microenvironment. ${ }^{118}$ However, analysis of Fc $\gamma$ RIIa and Fc $\gamma$ RIIIa polymorphisms showed no impact on PFS in the recent JAVELIN study of avelumab, an anti-PD-L1 antibody of IgG1 isotype, in patients with renal cell carcinoma. ${ }^{120}$ Fc-mediated effects also contribute to the activity of mAbs targeting cytotoxic $\mathrm{T}$ lymphocyte-associated antigen- 4 . Studies in mouse models demonstrate that the antitumor activity of ipilimumab (IgG1 isotype) is associated with depletion of intratumoral regulatory $\mathrm{T}$ (Treg) cells and increases in the CD8+ to Treg cell ratio. ${ }^{119}$ A meta-analysis of patients with advanced melanoma treated with ipilimumab revealed significantly higher response rates among Fc $\gamma$ RIIIa-158V carriers with high insertion-deletion mutations $(p=0.016)$ or high neoantigen burden $(p=0.043)$ compared with FcyRIIIa-158F homozygotes. ${ }^{119}$ Significantly longer OS was also found in Fc $\gamma$ RIIIa-158V carriers with high neoantigen burden $(\mathrm{p}=0.014)$ compared with Fc $\gamma$ RIIIa-158F homozygotes. ${ }^{119}$ The same meta-analysis 
did not find a correlation between FçRIIa-H131R polymorphisms and response rates or OS.

\section{Promotion of adaptive immunity by $\mathrm{Fc} \gamma \mathrm{Rs}$}

Fc $\gamma$ Rs can play a role in adaptive immune responses. ${ }^{36} 121$ Innate immune activation is known to contribute to $\mathrm{T}$ cell-mediated adaptive antitumor responses ${ }^{36}$ ADCC by activated NK cells or ADCP by macrophages or other immune cells cause tumor cell lysis, releasing tumor antigens that can be taken up and displayed on antigenpresenting cells to prime adaptive, $\mathrm{T}$ cell-mediated antitumor responses. ${ }^{9121}$ Activated NK cell cytokines facilitate macrophage and dendritic cell activation that in turn stimulates cytotoxic $\mathrm{T}$ cell migration to the intratumoral space. ${ }^{74121}$ ADCC and ADCP induced by treatment with antitumor mAbs generates antibody:tumor antigen immune complexes. ${ }^{29}$ Fc $\gamma \mathrm{R}$-dependent mechanisms contribute to the uptake and processing of these immune complexes by antigen-presenting cells, thus facilitating tumor antigen presentation to $\mathrm{T}$ cells, resulting in $\mathrm{T}$ cell memory responses and long-term antitumor vaccinal effects. ${ }^{29}$ Trastuzumab was found to increase HER2 antigen uptake by dendritic cells via an Fc $\gamma$ R-mediated mechanism. ${ }^{4}$ Specifically, increased HER2 antigen uptake resulted in cross-presentation of the E75 peptide, the immunodominant epitope derived from the HER2 protein, by dendritic cells, and this triggered priming of an antitumor immune response with increased antigenspecific cytotoxic $\mathrm{T}$ cell generation. ${ }^{4}$

Innate and adaptive immune systems cooperate in patients with breast cancer after trastuzumab therapy. ${ }^{67122}$ In a phase II study of neoadjuvant chemotherapy plus trastuzumab in patients with HER2+ breast cancer, those achieving a pCR had increased activated NK cell percentages and multiepitopic, polyfunctional (including HER2specific) antitumor $\mathrm{T}$ cell responses. ${ }^{122}$ Patients in the N9831 clinical trial who received adjuvant chemotherapy plus trastuzumab had higher post-treatment endogenous polyclonal anti-HER2 antibodies relative to those who received adjuvant chemotherapy alone. ${ }^{7}$ These data support that trastuzumab therapy could promote an adaptive immune response that in turn generates additional patient-derived anti-HER2 antibodies. Importantly, higher post-treatment anti-HER2 antibodies were associated with improved DFS. ${ }^{7}$ Similarly, analysis of patients with HER2+ MBC from two phase II trials (N0337 and N983252) revealed that trastuzumab-containing therapy led to generation of anti-HER2 antibodies that associated with improved PFS. ${ }^{6}$

Fc-engineered margetuximab was also associated with enhanced HER2-specific adaptive immune responses in patients with HER2+ breast, gastric, or other cancers treated with prior lines of HER2 antibody therapy. ${ }^{123-125}$ In these patients, post-treatment blood samples exhibited increased $\mathrm{T}$ cell clonality together with greatly increased frequencies of HER2-specific T cells and increased levels of HER2-specific antibodies compared with pretreatment samples. ${ }^{124} 125$ Similarly, increased frequencies of
HER2-specific T cells were observed in blood samples of patients with HER2+ GC in response to treatment with margetuximab and pembrolizumab. ${ }^{123}$

\section{Mechanism of action of margetuximab, an Fc-engineered anti-HER2 mAb}

The Fab portion of margetuximab shares HER2 specificity of trastuzumab, whereas the Fc portion is engineered. ${ }^{97} 98$ While trastuzumab is humanized, margetuximab is chimeric, comprising variable domains from the murine trastuzumab precursor and human IgG1 constant (Fc) domains. ${ }^{97} 98$ Direct (Fc-independent) properties of margetuximab are similar to those of trastuzumab; consequently, margetuximab and trastuzumab have similar binding affinity to HER2 protein and HER2+ cells, and antiproliferative activities of margetuximab and trastuzumab towards HER2+ tumor cells are similar (figure 1) ${ }^{82}$ Moreover, direct activity of both drugs can be improved by combination with pertuzumab, which binds to a different HER2 epitope. ${ }^{82}$ Fc-dependent properties of margetuximab, however, are enhanced compared with those of trastuzumab: margetuximab has higher binding affinity for both stronger-binding $158 \mathrm{~V}$ and weaker-binding $158 \mathrm{~F}$ allotypes of activating Fc $\gamma$ RIIIIa and decreased binding affinity for the inhibitory Fc $\gamma$ RIIb. ${ }^{97} 98$ Notably, margetuximab binds Fc $\gamma$ RIIIa-158F with higher affinity than trastuzumab binds Fc $\gamma$ RIIIa-158V. 829798

Margetuximab mediates ADCC more potently than trastuzumab in vitro ${ }^{9798}$ and ex vivo ${ }^{126}$ across all Fc $\gamma$ RIIIa genotypes. ${ }^{82}$ Correspondingly, margetuximab promotes greater NK cell activation and expansion/proliferation in vitro than does trastuzumab. ${ }^{82}$ Margetuximab also mediates ADCC in vitro with greater potency than pertuzumab. ${ }^{82}$ Moreover, margetuximab, with or without pertuzumab, mediates ADCC in vitro with greater potency than trastuzumab with pertuzumab. ${ }^{82} 127$

There are no direct comparisons of adaptive immune responses associated with margetuximab versus those associated with trastuzumab and pertuzumab. Based on comparisons across different independent studies that used comparable assay methods, increases in circulating HER2-specific antibody levels (mediated by B cells) were found in $42 \%-69 \%$ of trastuzumab-treated patients ${ }^{67}$ and in $94 \%$ of margetuximab-treated patients. ${ }^{125}$ Increases in $\mathrm{T}$ cell-mediated responses were found in $50 \%-78 \%$ of trastuzumab-treated patients ${ }^{8}$ and in $98 \%$ of margetuximab-treated patients. ${ }^{125}$

\section{Combinations of anti-HER2 antibodies with checkpoint inhibitors or co-stimulators}

Breast cancer has been traditionally considered poorly immunogenic, being characterized by relatively low tumor mutation burden. Nevertheless, recent evidence has revealed high tumor-infiltrating lymphocytes and PD-L1 expression in tumor-infiltrating lymphocytes and breast cancer cells in a considerable proportion of patients with HER2+ breast cancer. ${ }^{128}$ Moreover, trastuzumab has been shown to upregulate expression of PD-L1 in HER2+ breast 
cancer cells in the presence of immune effector cells, ${ }^{129}$ which may limit the extent of trastuzumab-mediated antitumor activity, since upregulation of the PD-1/PD-L1 pathway leads to immune evasion. In the NeoSphere trial testing neoadjuvant HER2-directed therapies in patients with early stage HER2+ breast cancer, higher mRNA expression of PD-1/PD-L1 in tumor tissue samples was associated with lower probability of pCR in the pertuzumab + trastuzumab + docetaxel arm. ${ }^{101}$

Based on these findings, numerous clinical trials evaluating combinations of anti-HER2 mAbs with checkpoint inhibitors are underway, with the goal of leveraging engagement of both innate and adaptive immunity. In the phase II portion of the PANACEA study, trastuzumab plus pembrolizumab (anti-PD-1, IgG4 isotype) showed 15\% ORR in patients with PD-L1-positive, trastuzumab-resistant, advanced HER2+ breast cancer, but there were no objective responses among the PD-L1-negative patients. ${ }^{130}$ In the Canadian Cancer Trials Group IND.229 phase Ib trial, trastuzumab plus durvalumab (anti-PD-1, IgG1 isotype engineered for reduced $\mathrm{Fc} \gamma \mathrm{R}$ binding) failed to demonstrate any responses in patients with HER2+, PD-L1-negative MBC. ${ }^{131}$ The combination of anti-HER2 therapy with checkpoint inhibitors has proven successful in patients with advanced HER2+ gastric or gastroesophageal junction adenocarcinoma (GEA). ${ }^{123} 132$ Based on the first interim results of the KEYNOTE-811 study, showing a 74\% ORR in the pembrolizumab arm versus 52\% in the placebo arm, the US Food and Drug Administration granted accelerated approval of pembrolizumab in combination with trastuzumab and fluoropyrimidine and platinum-based chemotherapy as first-line therapy for patients with HER2+ advanced GEA. ${ }^{132}$ A phase II study of margetuximab plus pembrolizumab in previously treated patients with advanced or metastatic HER2+ GEA showed encouraging antitumor activity, particularly in the subgroup of HER2 immunohistochemistry 3+ and PD-L1positive patients, with $44 \%$ ORR and $72 \%$ disease control rate. ${ }^{123}$ Furthermore, preliminary results of margetuximab plus tebotelimab (a bispecific anti-PD- $1 \times$ anti-lymphocyteactivating gene-3 dual-affinity re-targeting molecule) in a phase I study in patients with relapsed or refractory HER2+ tumors show an encouraging 21\% ORR. ${ }^{133} 134$

A phase II/III study (MAHOGANY) is underway to investigate margetuximab plus checkpoint inhibitors with or without chemotherapy in the first-line setting for patients with HER2+ GEA. ${ }^{135}$ An ongoing neoadjuvant investigator-sponsored phase II trial (MARGOT) is comparing margetuximab plus pertuzumab plus chemotherapy to trastuzumab plus pertuzumab plus chemotherapy in Fc $\gamma$ RIIIa-158F carriers with stage II/III HER2+ breast cancer. In this setting, the hypothesis of a superior efficacy in the margetuximab arm may be tested by using clinical end points (eg, pCR) as well as molecular and immune end points (eg, tumor-infiltrating lymphocyte rate, immune phenotype, natural anti-HER2 antibodies, or immune gene expression profiling).

Fc $\gamma$ RIIb expressed by immune effector cells serves as a checkpoint molecule based on its strong inhibitory effect on tumor targeting antibodies, which was unambiguously demonstrated in studies comparing the antitumor activity of trastuzumab in HER2+ tumor-bearing mice that were wild-type or genetically deleted for Fc $\gamma$ RIIb. $^{77}$ Adding to the complexity, there is preclinical evidence that for some agonistic anticancer antibodies, such as anti-DR5, anti-CD40, anti-CD137, and anti-OX40, cross-linking by Fc $\gamma \mathrm{RIIb}$ is necessary to successfully elicit antitumor responses. ${ }^{36}{ }^{117}$ In addition, Fc $\gamma$ RIIb expressed on tumor cells can contribute to resistance to tumor-targeting antibodies by facilitating internalization of tumor antigens. ${ }^{136}$ Targeted blockade of Fc $\gamma$ RIIb may help overcome resistance and boost activity of clinically validated and emerging antibodies in cancer immunotherapy. ${ }^{36}$ Antibodies specific to human Fc $\gamma$ RIIb (which do not react with the FcyRIIa) have been isolated ${ }^{137138}$ and shown to be capable of blocking the inhibitory effect of Fc $\gamma$ RIIb. ${ }^{137}$ Early stage clinical trials are ongoing to evaluate FcyRIIbblocking antibody BI-1206 as a single agent and combined with rituximab or pembrolizumab in B cell malignancy. ${ }^{36}$

CD137 (4-1BB) is an activation-induced costimulatory molecule that is expressed on activated T cells, NK cells, dendritic cells, eosinophils, mast cells, endothelial cells, and some tumor cells. ${ }^{139}$ Ligation of CD137 by agonistic antibodies provides a costimulatory signal in multiple immune cell subsets, including enhancement of ADCC and ADCP. ${ }^{140}$ For example, an anti-CD137 mAb enhances trastuzumab-induced, NK-mediated ADCC against pancreatic cancer cell lines, even with relatively low amounts of HER2 expression. ${ }^{141}$ A phase I clinical study (NCT01307267) tested the CD137 agonist mAb utomilumab in combination with rituximab in patients with relapsed/refractory follicular lymphoma and other CD20+ non-Hodgkin's lymphomas. ${ }^{142}$ The study demonstrated anecdotal clinical activity and a favorable safety profile. ${ }^{142}$ Although the utomilumab sponsor recently deprioritized its further development in solid tumors, an investigator-initiated phase IB/II clinical trial of utomilumab plus either trastuzumab or T-DM1 in refractory HER2+ MBC is ongoing and has not yet reported results (NCT03364348). Whether or not this trial, or future investigation of margetuximab combined with a CD137 agonist, could renew interest in this approach remains to be explored. Another approach, consisting of a bispecific trivalent HER $2 \times$ CD $137 \times$ CD1 137 construct, could be useful to further assess the validity of the combinatorial strategy of CD137 agonism plus HER2 blockade. ${ }^{143}$

\section{Future directions}

The anti-HER2 mAb landscape continues to evolve, with several approved trastuzumab biosimilars, a recently approved novel anti-HER2 ADC (DS-8201a, trastuzumab deruxtecan), ${ }^{144}$ and another (SYD985) ${ }^{145}$ in late-stage clinical trials. Equally notable are recent approvals of anti-HER2 tyrosine kinase inhibitors tucatinib and neratinib. In addition, there are HER2-bispecific mAbs in phase II clinical trials. Zanidatamab (or ZW25; binding the two distinct HER2 epitopes targeted by trastuzumab 
and pertuzumab) ${ }^{146}$ is being tested in phase II studies (in HER2+/HR+ advanced breast cancer, in HER2+ advanced GEA, and in advanced HER2+ biliary tract cancers). Also, zenocutuzumab (or MCLA-128; targeting both HER2 and HER3) ${ }^{147}$ is being tested in a phase II study in patients with MBC with either HER2+ tumors or with estrogen receptor+/low HER2 expression.

Novel chimeric antigen receptor-T cells have also been developed to engage the Fc domain of tumorspecific mAbs. In particular, an innovative construct (antibody-coupled $\mathrm{T}$ cell receptor) has been designed with Fc $\gamma$ RIIIa-158V extracellular domain, CD8 hinge and transmembrane domains, and $4-1 \mathrm{BB}$ and $\mathrm{CD} 3 \zeta$ intracellular signaling domains. ${ }^{148}$ When these engineered T cells are transferred back into patients, they can be directed against HER2+ tumors by co-administering anti-HER2 mAbs with functional Fc domains, such as trastuzumab.

Additional bispecific anti-HER2 mAbs are in preclinical development. HER2(Per)-S-Fab, developed by linking the pertuzumab Fab to an anti-Fc $\gamma$ RIIIa singledomain antibody, showed potent cytotoxicity against HER2+ tumor cells in vitro and tumor growth inhibition in vivo. ${ }^{149}$ HER2-BsAb, designed for bivalent binding to HER2 (same specificity as trastuzumab) and monovalent binding to $\mathrm{CD} 3$, includes a silenced $\mathrm{Fc}$ domain to reduce risk of cytokine release syndrome. ${ }^{150}$ HER2-BsAb is able to redirect $\mathrm{T}$ cells against established tumors and has exhibited increased antitumor activity versus trastuzumab both in vitro and in vivo. ${ }^{150}$

\section{Conclusions}

We have reviewed that Fc $\gamma$ R-dependent activity is an important contributor to the mechanism of action of antitumor therapeutic mAbs, as demonstrated by (1) Differential antitumor responses based on patterns of Fc domain glycosylation (whether deliberate or accidental) that impact on Fc $\gamma \mathrm{R}$ binding, (2) Influence of $\mathrm{Fc} \gamma \mathrm{R}$ genotypes on clinical response to trastuzumab in HER2+ breast cancer, and (3) Fc-domain engineering

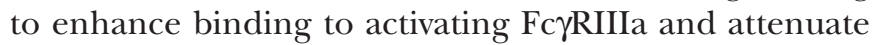
binding to inhibitory Fc $\gamma$ RIIb. Fc domain engineering has been shown to be clinically feasible and active in the case of margetuximab, ${ }^{58}$ leading to US Food and Drug Administration approval (the first for an Fc-engineered antibody) in patients with HER2+ MBCwho have received two or more prior anti-HER2 regimens, with at least one for metastatic disease.

Present affiliations The present affiliation of Edwin P Rock is: Partner Therapeutics, Massachusetts, Lexington, USA and Fernanda Arnaldez is: AstraZeneca, Maryland, Gaithersburg, USA.

Acknowledgements The authors thank Emily Cullinan, PhD, CMPP, and Francesca Balordi, PhD, CMPP, of The Lockwood Group (Stamford, Connecticut, USA), for the professional editorial support provided by them in accordance with Good Publication Practice (GPP3) guidelines.

Contributors MDP provided direction and guidance throughout the preparation of this manuscript. All authors reviewed and edited the manuscript. All authors approved the final manuscript. MDP is responsible for the overall content as the guarantor.
Funding MacroGenics, Inc. (Rockville, Maryland, USA) provided funding.

Competing interests AM reports grants from Roche and Eisai; personal fees from MacroGenics, Roche, Eisai, Novartis, and Lilly; participation in advisory boards from MacroGenics, Roche, Eisai, Novartis, Lilly. WJG has nothing to disclose. HSR reports personal fees for short-term consulting from Puma and Samsung; institutional grants for clinical research study activities from MacroGenics, Roche, Pfizer, Novartis, Lilly, Merck, Seattle Genetics, Odonate Therapeutics, Eisai, Sermonix, and Immunomedics, Daiichi Sankyo. MDP reports personal consulting fees from MacroGenics, AstraZeneca/Daiichi Sankyo, Pfizer, and Roche/Genentech, and grant support on this topic from the Parker Institute for Cancer Immunotherapy and the Mary Kay Foundation. JLN is an employee of MacroGenics. EPR was an employee of MacroGenics and is now an employee of Partner Therapeutics. FA was an employee of MacroGenics and is now an employee of AstraZeneca.

Patient consent for publication Not applicable.

Provenance and peer review Not commissioned; externally peer reviewed.

Supplemental material This content has been supplied by the author(s). It has not been vetted by BMJ Publishing Group Limited (BMJ) and may not have been peer-reviewed. Any opinions or recommendations discussed are solely those of the author(s) and are not endorsed by BMJ. BMJ disclaims all liability and responsibility arising from any reliance placed on the content. Where the content includes any translated material, BMJ does not warrant the accuracy and reliability of the translations (including but not limited to local regulations, clinical guidelines, terminology, drug names and drug dosages), and is not responsible for any error and/or omissions arising from translation and adaptation or otherwise.

Open access This is an open access article distributed in accordance with the Creative Commons Attribution Non Commercial (CC BY-NC 4.0) license, which permits others to distribute, remix, adapt, build upon this work non-commercially, and license their derivative works on different terms, provided the original work is properly cited, appropriate credit is given, any changes made indicated, and the use is non-commercial. See http://creativecommons.org/licenses/by-nc/4.0/.

\section{ORCID iD}

Hope S Rugo http://orcid.org/0000-0001-6710-4814

\section{REFERENCES}

1 Slamon D, Eiermann W, Robert N, et al. Adjuvant trastuzumab in HER2-positive breast cancer. N Engl J Med 2011;365:1273-83.

2 Slamon DJ, Leyland-Jones B, Shak S, et al. Use of chemotherapy plus a monoclonal antibody against HER2 for metastatic breast cancer that overexpresses HER2. N Engl J Med 2001;344:783-92.

3 Arnould L, Gelly M, Penault-Llorca F, et al. Trastuzumab-based treatment of HER2-positive breast cancer: an antibody-dependent cellular cytotoxicity mechanism? Br J Cancer 2006;94:259-67.

4 Gall VA, Philips AV, Qiao N, et al. Trastuzumab increases HER2 uptake and cross-presentation by dendritic cells. Cancer Res 2017;77:5374-83.

5 Gül N, van Egmond M. Antibody-dependent phagocytosis of tumor cells by macrophages: a potent effector mechanism of monoclonal antibody therapy of cancer. Cancer Res 2015;75:5008-13.

6 Knutson KL, Clynes R, Shreeder B, et al. Improved survival of HER2+ breast cancer patients treated with trastuzumab and chemotherapy is associated with host antibody immunity against the HER2 intracellular domain. Cancer Res 2016;76:3702-10.

7 Norton N, Fox N, McCarl C-A, et al. Generation of HER2-specific antibody immunity during trastuzumab adjuvant therapy associates with reduced relapse in resected HER2 breast cancer. Breast Cancer Res 2018;20:52.

8 Taylor C, Hershman D, Shah N, et al. Augmented HER-2 specific immunity during treatment with trastuzumab and chemotherapy. Clin Cancer Res 2007;13:5133-43.

9 Barnhart BC, Quigley M. Role of Fc-FcgammaR interactions in the antitumor activity of therapeutic antibodies. Immunol Cell Biol 2017;95:340-6.

10 Nimmerjahn F, Ravetch JV. Fcgamma receptors as regulators of immune responses. Nat Rev Immunol 2008;8:34-47.

11 Vogelpoel LTC, Baeten DLP, de Jong EC, et al. Control of cytokine production by human Fc gamma receptors: implications for pathogen defense and autoimmunity. Front Immunol 2015;6:79.

12 Ben Mkaddem S, Benhamou M, Monteiro RC. Understanding FC receptor involvement in inflammatory diseases: from mechanisms to new therapeutic tools. Front Immunol 2019;10:811. 
13 Benonisson H, Sow HS, Breukel C, et al. High FcyR expression on intratumoral macrophages enhances tumor-targeting antibody therapy. J Immunol 2018;201:3741-9.

14 Capietto A-H, Martinet L, Fournié J-J. Stimulated gammadelta T cells increase the in vivo efficacy of trastuzumab in HER-2+ breast cancer. $\mathrm{J}$ Immunol 2011;187:1031-8.

15 Clémenceau B, Vivien R, Berthomé M, et al. Effector memory alphabeta T lymphocytes can express FcgammaRIlla and mediate antibody-dependent cellular cytotoxicity. J Immunol 2008;180:5327-34

16 Dutertre C-A, Bonnin-Gélizé E, Pulford K, et al. A novel subset of NK cells expressing high levels of inhibitory FcgammaRIIB modulating antibody-dependent function. J Leukoc Biol 2008;84:1511-20.

17 Metes D, Ernst LK, Chambers WH, et al. Expression of functional CD32 molecules on human NK cells is determined by an allelic polymorphism of the FcgammaRIIC gene. Blood 1998;91:2369-80.

18 Mueller M, Barros P, Witherden AS, et al. Genomic pathology of SLE-associated copy-number variation at the FCGR2C/FCGR3B/ FCGR2B locus. Am J Hum Genet 2013;92:28-40.

19 Schmitz M, Zhao S, Schäkel K, et al. Native human blood dendritic cells as potent effectors in antibody-dependent cellular cytotoxicity. Blood 2002;100:1502-4.

20 Seidel UJE, Vogt F, Grosse-Hovest L, et al. $\gamma \delta$ T cell-mediated antibody-dependent cellular cytotoxicity with CD19 antibodies assessed by an impedance-based label-free real-time cytotoxicity assay. Front Immunol 2014;5:618.

21 Shi Y, Fan X, Deng H, et al. Trastuzumab triggers phagocytic killing of high HER2 cancer cells in vitro and in vivo by interaction with Fcgamma receptors on macrophages. $J$ Immunol 2015;194:4379-86.

22 Su K, Wu J, Edberg JC, et al. Genomic organization of classical human low-affinity Fcgamma receptor genes. Genes Immun 2002;3:S51-6.

23 Vivier E, Ugolini S, Blaise D, et al. Targeting natural killer cells and natural killer T cells in cancer. Nat Rev Immunol 2012;12:239-52.

24 Wieckowski S, Avenal C, Orjalo AV, et al. Toward a better understanding of bioassays for the development of biopharmaceuticals by exploring the structure-antibody-dependent cellular cytotoxicity relationship in human primary cells. Front Immunol 2020;11:552596.

25 Xie Z, Zheng J, Wang Y, et al. Deficient IL-2 produced by activated $\mathrm{CD}^{+}{ }^{+} \mathrm{T}$ cells contributes to impaired NK cell-mediated ADCC function in chronic HIV-1 infection. Front Immunol 2019;10:1647.

26 Yeap WH, Wong KL, Shimasaki N, et al. CD16 is indispensable for antibody-dependent cellular cytotoxicity by human monocytes. Sci Rep 2016;6:34310.

27 Anania JC, Chenoweth AM, Wines BD, et al. The human FcyRll (CD32) family of leukocyte FcR in health and disease. Front Immunol 2019;10:464.

28 Chen X, Song X, Li K, et al. FcgammaR-binding is an important functional attribute for immune checkpoint antibodies in cancer immunotherapy. Front Immunol 2019;10:292.

29 DiLillo DJ, Ravetch JV. Differential Fc-receptor engagement drives an anti-tumor vaccinal effect. Cell 2015;161:1035-45.

30 Golay J, Valgardsdottir R, Musaraj G, et al. Human neutrophils express low levels of FcgammaRIIIA, which plays a role in PMN activation. Blood 2019;133:1395-405.

31 Punt J, Stranford SA, Jones PP. Kuby immunology. 8th edn. New York, NY: W.H. Freeman and Company, 2019.

32 Treffers LW, van Houdt M, Bruggeman CW, et al. Fcyrlllb restricts antibody-dependent destruction of cancer cells by human neutrophils. Front Immunol 2018:9:3124.

33 Zhang $\mathrm{H}$, Verkman AS. Eosinophil pathogenicity mechanisms and therapeutics in neuromyelitis optica. $J$ Clin Invest 2013;123:2306-16.

34 Nimmerjahn F, Ravetch JV. Fcgamma receptors: old friends and new family members. Immunity 2006;24:19-28.

35 Swisher JFA, Feldman GM. The many faces of FcgammaRI: implications for therapeutic antibody function. Immunol Rev 2015;268:160-74.

36 Teige I, Mårtensson L, Frendéus BL. Targeting the antibody checkpoints to enhance cancer immunotherapy-focus on FcgammaRIIB. Front Immunol 2019:10:481.

37 van der Heijden J, Breunis WB, Geissler J, et al. Phenotypic variation in IgG receptors by nonclassical FCGR2C alleles. $\mathrm{J}$ Immunol 2012;188:1318-24.

38 Boylan B, Gao C, Rathore V, et al. Identification of FcgammaRlla as the ITAM-bearing receptor mediating alphallbbeta3 outside-in integrin signaling in human platelets. Blood 2008;112:2780-6.
39 Chauhan AK. Human CD4(+) T-cells: a role for low-affinity Fc receptors. Front Immunol 2016;7:215.

40 Holgado MP, Sananez I, Raiden S, et al. CD32 ligation promotes the activation of $\mathrm{CD}^{+} \mathrm{T}$ cells. Front Immunol 2018;9:2814.

41 Farley CR, Morris AB, Tariq M, et al. FcyRIIB is a T cell checkpoint in antitumor immunity. JCl Insight 2021;6 doi:10.1172/jci. insight. 135623

42 Ganesan LP, Kim J, Wu Y, et al. FcgammaRllb on liver sinusoidal endothelium clears small immune complexes. J Immunol 2012;189:4981-8.

43 Gillis C, Gouel-Chéron A, Jönsson F, et al. Contribution of human FcyRs to disease with evidence from human polymorphisms and transgenic animal studies. Front Immunol 2014;5:254.

44 Cartron G, Dacheux L, Salles G, et al. Therapeutic activity of humanized anti-CD20 monoclonal antibody and polymorphism in IgG Fc receptor FcgammaRIlla gene. Blood 2002;99:754-8.

45 Gavin PG, Song N, Kim SR, et al. Association of polymorphisms in FCGR2A and FCGR3A with degree of trastuzumab benefit in the adjuvant treatment of ERBB2/HER2-positive breast cancer: analysis of the NSABP B-31 trial. JAMA Oncol 2017;3:335-41.

46 Hurvitz SA, Betting DJ, Stern HM, et al. Analysis of Fcgamma receptor IIIA and IIA polymorphisms: lack of correlation with outcome in trastuzumab-treated breast cancer patients. Clin Cancer Res 2012;18:3478-86.

47 Koene HR, Kleijer M, Algra J, et al. FcyRllla-158V/F polymorphism influences the binding of IgG by natural killer cell FcyRllla, independently of the FcyRllla-48L/R/H phenotype. Blood 1997;90:1109-14

48 Kyogoku C, Dijstelbloem HM, Tsuchiya N, et al. Fcgamma receptor gene polymorphisms in Japanese patients with systemic lupus erythematosus: contribution of FCGR2B to genetic susceptibility. Arthritis Rheum 2002;46:1242-54.

49 Lehrnbecher T, Foster CB, Zhu S, et al. Variant genotypes of the low-affinity Fcgamma receptors in two control populations and a review of low-affinity Fcgamma receptor polymorphisms in control and disease populations. Blood 1999;94:4220-32.

50 Magnes T, Melchardt T, Hufnagl C, et al. The influence of FCGR2A and FCGR3A polymorphisms on the survival of patients with recurrent or metastatic squamous cell head and neck cancer treated with cetuximab. Pharmacogenomics J 2018;18:474-9.

51 Mahaweni NM, Olieslagers TI, Rivas IO, et al. A comprehensive overview of FCGR3A gene variability by full-length gene sequencing including the identification of V158F polymorphism. Sci Rep 2018;8:15983.

52 Milicic A, Misra R, Agrawal S, et al. The F158V polymorphism in FcgammaRIIIA shows disparate associations with rheumatoid arthritis in two genetically distinct populations. Ann Rheum Dis 2002;61:1021-3.

53 Morgan AW, Keyte VH, Babbage SJ, et al. FcgammaRIIIA-158V and rheumatoid arthritis: a confirmation study. Rheumatology (Oxford) 2003;42:528-33.

54 Musolino A, Naldi N, Bortesi B, et al. Immunoglobulin G fragment C receptor polymorphisms and clinical efficacy of trastuzumab-based therapy in patients with HER-2/neu-positive metastatic breast cancer. J Clin Oncol 2008;26:1789-96.

55 Musolino A, Naldi N, Dieci MV, et al. Immunoglobulin G fragment C receptor polymorphisms and efficacy of preoperative chemotherapy plus trastuzumab and lapatinib in HER2-positive breast cancer. Pharmacogenomics J 2016;16:472-7.

56 Norton N, Olson RM, Pegram M, et al. Association studies of Fcgamma receptor polymorphisms with outcome in HER2+ breast cancer patients treated with trastuzumab in NCCTG (Alliance) Trial N9831. Cancer Immunol Res 2014;2:962-9.

57 Persky DO, Dornan D, Goldman BH, et al. Fc gamma receptor 3A genotype predicts overall survival in follicular lymphoma patients treated on SWOG trials with combined monoclonal antibody plus chemotherapy but not chemotherapy alone. Haematologica 2012;97:937-42.

58 Rugo HS, Im S-A, Cardoso F, et al. Efficacy of margetuximab vs trastuzumab in patients with pretreated ERBB2-positive advanced breast cancer: a phase 3 randomized clinical trial. JAMA Oncol 2021;7:573-84

59 Tamura K, Shimizu C, Hojo T, et al. FcgammaR2A and 3A polymorphisms predict clinical outcome of trastuzumab in both neoadjuvant and metastatic settings in patients with HER2-positive breast cancer. Ann Oncol 2011;22:1302-7.

60 Tanaka Y, Suzuki Y, Tsuge T, et al. FcgammaRlla-131R allele and FcgammaRIlla-176V/N genotype are risk factors for progression of IgA nephropathy. Nephrol Dial Transplant 2005;20:2439-45.

61 Tout M, Gagez A-L, Leprêtre S, et al. Influence of FCGR3A$158 \mathrm{~V} / \mathrm{F}$ genotype and baseline CD20 antigen count on target- 
mediated elimination of rituximab in patients with chronic lymphocytic leukemia: a study of FILO group. Clin Pharmacokinet 2017;56:635-47.

62 Wang D-S, Wei X-L, Wang Z-Q, et al. FcgammaRIIA and IIIA polymorphisms predict clinical outcome of trastuzumab-treated metastatic gastric cancer. Onco Targets Ther 2017;10:5065-76.

63 Weng W-K, Levy R. Two immunoglobulin G fragment C receptor polymorphisms independently predict response to rituximab in patients with follicular lymphoma. J Clin Oncol 2003;21:3940-7.

64 Wu J, Edberg JC, Redecha PB, et al. A novel polymorphism of FcgammaRIIla (CD16) alters receptor function and predisposes to autoimmune disease. J Clin Invest 1997;100:1059-70.

65 Arnold ML, Kainz A, Hidalgo LG, et al. Functional Fc gamma receptor gene polymorphisms and donor-specific antibodytriggered microcirculation inflammation. Am J Transplant 2018;18:2261-73

66 Ghesquières $\mathrm{H}$, Larrabee $\mathrm{BR}$, Haioun $\mathrm{C}$, et al. FCGR3A/2A polymorphisms and diffuse large B-cell lymphoma outcome treated with immunochemotherapy: a meta-analysis on 1134 patients from two prospective cohorts. Hematol Oncol 2017;35:447-55.

67 Pavkovic M, Petlichkovski A, Karanfilski O, et al. FC gamma receptor polymorphisms in patients with immune thrombocytopenia. Hematology 2018;23:163-8.

$68 \mathrm{Li} \mathrm{X}, \mathrm{Wu}$ J, Carter RH, et al. A novel polymorphism in the Fcgamma receptor IIB (CD32B) transmembrane region alters receptor signaling. Arthritis Rheum 2003;48:3242-52.

69 Magnusson V, Zunec R, Odeberg J, et al. Polymorphisms of the FC gamma receptor type IIB gene are not associated with systemic lupus erythematosus in the Swedish population. Arthritis Rheum 2004;50:1348-50.

70 Willcocks LC, Carr EJ, Niederer HA, et al. A defunctioning polymorphism in FCGR2B is associated with protection against malaria but susceptibility to systemic lupus erythematosus. Proc Natl Acad Sci U S A 2010;107:7881-5.

71 Chen J-Y, Wang CM, Ma C-C, et al. Association of a transmembrane polymorphism of Fcgamma receptor Ilb (FCGR2B) with systemic lupus erythematosus in Taiwanese patients. Arthritis Rheum 2006;54:3908-17.

72 Koga M, Kawasaki A, Ito I, et al. Cumulative association of eight susceptibility genes with systemic lupus erythematosus in a Japanese female population. J Hum Genet 2011;56:503-7.

73 Zidan HE, Sabbah NA, Hagrass HA, et al. Association of FcgammaRIIB and FcgammaRIIA R131H gene polymorphisms with renal involvement in Egyptian systemic lupus erythematosus patients. Mol Biol Rep 2014;41:733-9.

74 Muntasell A, Cabo M, Servitja S, et al. Interplay between natural killer cells and anti-HER2 antibodies: perspectives for breast cancer immunotherapy. Front Immunol 2017;8:1544.

75 Boivin WA, Cooper DM, Hiebert PR, et al. Intracellular versus extracellular granzyme $B$ in immunity and disease: challenging the dogma. Lab Invest 2009;89:1195-220.

76 Bots M, Medema JP. Granzymes at a glance. J Cell Sci 2006;119:5011-4

77 Clynes RA, Towers TL, Presta LG, et al. Inhibitory Fc receptors modulate in vivo cytotoxicity against tumor targets. Nat Med 2000;6:443-6.

78 Negri FV, Musolino A, Naldi N, et al. Role of immunoglobulin G fragment $C$ receptor polymorphism-mediated antibody-dependant cellular cytotoxicity in colorectal cancer treated with cetuximab therapy. Pharmacogenomics J 2014;14:14-19.

79 Robak T, Robak E. New anti-CD20 monoclonal antibodies for the treatment of B-cell lymphoid malignancies. BioDrugs $2011 ; 25: 13-25$.

80 Pegram MD, Baly D, Wirth C. Antibody dependent cell-mediated cytotoxicity in breast cancer patients in phase III clinical trials of a humanized anti-HER2 antibody. Proc Am Assoc Cancer Res 1997;38:Abstract 602

81 Junttila TT, Li G, Parsons K, et al. Trastuzumab-DM1 (T-DM1) retains all the mechanisms of action of trastuzumab and efficiently inhibits growth of lapatinib insensitive breast cancer. Breast Cancer Res Treat 2011;128:347-56.

82 Liu L, Yang Y, Burns R. Margetuximab mediates greater Fcdependent anti-tumor activities than trastuzumab or pertuzumab in vitro. Cancer Res 2019;79:Abstract 1538.

83 Scheuer W, Friess T, Burtscher $\mathrm{H}$, et al. Strongly enhanced antitumor activity of trastuzumab and pertuzumab combination treatment on HER2-positive human xenograft tumor models. Cancer Res 2009;69:9330-6.

84 Swain SM, Miles D, Kim S-B, et al. Pertuzumab, trastuzumab, and docetaxel for HER2-positive metastatic breast cancer (CLEOPATRA): end-of-study results from a double-blind, randomised, placebo-controlled, phase 3 study. Lancet Oncol 2020;21:519-30.

85 Gianni L, Pienkowski T, Im Y-H, et al. 5-year analysis of neoadjuvant pertuzumab and trastuzumab in patients with locally advanced, inflammatory, or early-stage HER2-positive breast cancer (NeoSphere): a multicentre, open-label, phase 2 randomised trial. Lancet Oncol 2016;17:791-800.

86 Zitvogel L, Apetoh L, Ghiringhelli F, et al. Immunological aspects of cancer chemotherapy. Nat Rev Immunol 2008;8:59-73.

87 Di Modica M, Sfondrini L, Regondi V, et al. Taxanes enhance trastuzumab-mediated ADCC on tumor cells through NKG2Dmediated NK cell recognition. Oncotarget 2016;7:255-65.

$88 \mathrm{Kim} \mathrm{S}$, Song J, Park S, et al. Drifts in ADCC-related quality attributes of Herceptin $\circledast$ : impact on development of a trastuzumab biosimilar. MAbs 2017:9:704-14.

89 Pivot X, Pegram M, Cortes J, et al. Three-year follow-up from a phase 3 study of SB3 (a trastuzumab biosimilar) versus reference trastuzumab in the neoadjuvant setting for human epidermal growth factor receptor 2-positive breast cancer. Eur J Cancer 2019;120:1-9.

90 Dokter W, Ubink R, van der Lee M, et al. Preclinical profile of the HER2-targeting ADC SYD983/SYD985: introduction of a new duocarmycin-based linker-drug platform. Mol Cancer Ther 2014;13:2618-29.

91 Ogitani Y, Hagihara K, Oitate M, et al. Bystander killing effect of DS-8201a, a novel anti-human epidermal growth factor receptor 2 antibody-drug conjugate, in tumors with human epidermal growth factor receptor 2 heterogeneity. Cancer Sci 2016:107:1039-46.

92 Wang X, Mathieu M, Brezski RJ. IgG Fc engineering to modulate antibody effector functions. Protein Cell 2018;9:63-73.

93 Pereira NA, Chan KF, Lin PC, et al. The "less-is-more" in therapeutic antibodies: afucosylated anti-cancer antibodies with enhanced antibody-dependent cellular cytotoxicity. MAbs 2018;10:693-711.

94 Shinkawa T, Nakamura K, Yamane N, et al. The absence of fucose but not the presence of galactose or bisecting $\mathrm{N}$-acetylglucosamine of human lgG1 complex-type oligosaccharides shows the critical role of enhancing antibody-dependent cellular cytotoxicity. J Biol Chem 2003;278:3466-73.

95 Fiedler W, Stoeger H, Perotti A, et al. Phase I study of TrasGEX, a glyco-optimised anti-HER2 monoclonal antibody, in patients with HER2-positive solid tumours. ESMO Open 2018;3:e000381.

96 Suzuki E, Niwa R, Saji S, et al. A nonfucosylated anti-HER2 antibody augments antibody-dependent cellular cytotoxicity in breast cancer patients. Clin Cancer Res 2007;13:1875-82.

97 Nordstrom JL, Gorlatov S, Zhang W, et al. Anti-tumor activity and toxicokinetics analysis of MGAH22, an anti-HER2 monoclonal antibody with enhanced Fcgamma receptor binding properties. Breast Cancer Res 2011;13:R123.

98 Stavenhagen JB, Gorlatov S, Tuaillon N, et al. Fc optimization of therapeutic antibodies enhances their ability to kill tumor cells in vitro and controls tumor expansion in vivo via low-affinity activating Fcgamma receptors. Cancer Res 2007:67:8882-90.

99 Xiao H, Woods EC, Vukojicic P, et al. Precision glycocalyx editing as a strategy for cancer immunotherapy. Proc Natl Acad Sci U S A 2016;113:10304-9.

100 Maruyama T, Mimura K, Izawa S, et al. Lapatinib enhances herceptin-mediated antibody-dependent cellular cytotoxicity by up-regulation of cell surface HER2 expression. Anticancer Res 2011;31:2999-3005.

101 Musolino A, Boggiani D, Pellegrino B, et al. Role of innate and adaptive immunity in the efficacy of anti-HER2 monoclonal antibodies for HER2-positive breast cancer. Crit Rev Oncol Hematol 2020;149:102927.

102 Oberg HH, Kellner C, Gonnermann D, et al. Tribody [(HER $\left.)_{2} \times C D 16\right]$ is more effective than trastuzumab in enhancing $\gamma \delta \mathrm{T}$ cell and natural killer cell cytotoxicity against $\mathrm{HER}_{2}$-expressing cancer cells. Front Immunol 2018:9:814.

103 Qian B-Z, Pollard JW. Macrophage diversity enhances tumor progression and metastasis. Cell 2010;141:39-51.

104 Grugan KD, McCabe FL, Kinder M, et al. Tumor-associated macrophages promote invasion while retaining $\mathrm{Fc}$-dependent antitumor function. J Immunol 2012;189:5457-66.

105 Yin J, Albers AJ, Smith TS, et al. Differential regulation of human monocytes and NK cells by antibody-opsonized tumors. Cancer Immunol Immunother 2018:67:1239-50.

106 Herter S, Birk MC, Klein C, et al. Glycoengineering of therapeutic antibodies enhances monocyte/macrophage-mediated phagocytosis and cytotoxicity. J Immunol 2014;192:2252-60.

107 Richards JO, Karki S, Lazar GA, et al. Optimization of antibody binding to FcgammaRIla enhances macrophage phagocytosis of tumor cells. Mol Cancer Ther 2008;7:2517-27. 
108 Zhang H, Lu H, Xiang L, et al. HIF-1 regulates CD47 expression in breast cancer cells to promote evasion of phagocytosis and maintenance of cancer stem cells. Proc Natl Acad Sci U S A 2015;112:E6215-23.

109 Tsao L-C, Crosby EJ, Trotter TN. Cd47 blockade augmentation of trastuzumab antitumor efficacy dependent on antibody-dependent cellular phagocytosis. JCl Insight 2019;4:e131882.

110 Upton R, Feng D, Banuelos AM. Humanized anti-CD47 monoclonal antibody magrolimab (Hu5F9-G4) plus trastuzumab potentiates antibody-dependent cellular phagocytosis (ADCP), and cooperate to inhibit human HER2+ breast cancer (BC) xenografts growth in vivo. Abstract PS17-06. Cancer Res 2021;81:PS17-06.

111 Hu X, Liu Y, Zhang X, et al. The anti-B7-H4 checkpoint synergizes trastuzumab treatment to promote phagocytosis and eradicate breast cancer. Neoplasia 2020;22:539-53.

112 Laengle J, Kabiljo J, Hunter L. Histone deacetylase inhibitors valproic acid and vorinostat enhance trastuzumab-mediated antibody-dependent cell-mediated phagocytosis. J Immunother Cancer 2020;8:e000195.

113 Botticelli A, Mazzuca F, Borro M, et al. FCGRs polymorphisms and response to trastuzumab in patients with HER2-positive breast cancer: far from predictive value? World J Oncol 2015;6:437-40.

114 Romond EH, Perez EA, Bryant J, et al. Trastuzumab plus adjuvant chemotherapy for operable HER2-positive breast cancer. N Engl J Med 2005;353:1673-84.

115 Roca L, Diéras V, Roché $\mathrm{H}$, et al. Correlation of HER2, FCGR2A, and FCGR3A gene polymorphisms with trastuzumab related cardiac toxicity and efficacy in a subgroup of patients from UNICANCERPACS 04 trial. Breast Cancer Res Treat 2013;139:789-800.

116 Mellor JD, Brown MP, Irving HR, et al. A critical review of the role of Fc gamma receptor polymorphisms in the response to monoclonal antibodies in cancer. J Hematol Oncol 2013;6:1.

117 Liu R, Oldham RJ, Teal E. FC-engineering for modulated effector functions-improving antibodies for cancer treatment. Antibodies 2020;9:64

118 Dahan R, Sega E, Engelhardt J, et al. FcgammaRs modulate the anti-tumor activity of antibodies targeting the PD-1/PD-L1 axis. Cancer Cell 2015;28:285-95.

119 Arce Vargas F, Furness AJS, Litchfield K, et al. Fc effector function contributes to the activity of human anti-CTLA-4 antibodies. Cancer Cell 2018;33:649-63.

120 Motzer RJ, Robbins PB, Powles T, et al. Avelumab plus axitinib versus sunitinib in advanced renal cell carcinoma: biomarker analysis of the phase 3 JAVELIN renal 101 trial. Nat Med 2020;26:1733-41.

121 Ferris RL, Lenz H-J, Trotta AM, et al. Rationale for combination of therapeutic antibodies targeting tumor cells and immune checkpoint receptors: harnessing innate and adaptive immunity through IgG1 isotype immune effector stimulation. Cancer Treat Rev 2018;63:48-60.

122 Muraro E, Comaro E, Talamini R, et al. Improved natural killer cell activity and retained anti-tumor CD8(+) T cell responses contribute to the induction of a pathological complete response in HER2-positive breast cancer patients undergoing neoadjuvant chemotherapy. J Transl Med 2015;13:204.

123 Catenacci DVT, Kang Y-K, Park H, et al. Margetuximab plus pembrolizumab in patients with previously treated, HER2-positive gastro-oesophageal adenocarcinoma (CP-MGAH22-05): a singlearm, phase 1b-2 trial. Lancet Oncol 2020;21:1066-76.

124 S-A I, Bang Y-J, D-Y O. Long-term responders to single-agent margetuximab, an Fc-modified anti-HER2 monoclonal antibody, in metastatic HER2+ breast cancer patients with prior anti-HER2 therapy. Cancer Res 2019;79:Abstract P6-18-11.

125 Nordstrom JL, Muth J, Erskine CL. High frequency of HER2-specific immunity observed in patients (pts) with HER2+ cancers treated with margetuximab (M), an Fc-enhanced anti-HER2 monoclonal antibody (mAb). J Clin Oncol 2019;37:1030.

126 Bang YJ, Giaccone G, Im SA, et al. First-in-human phase 1 study of margetuximab (MGAH22), an Fc-modified chimeric monoclonal antibody, in patients with HER2-positive advanced solid tumors. Ann Oncol 2017;28:855-61.

127 Tóth G, Szöör Árpád, Simon L, et al. The combination of trastuzumab and pertuzumab administered at approved doses may delay development of trastuzumab resistance by additively enhancing antibody-dependent cell-mediated cytotoxicity. MAbs 2016;8:1361-70.

128 Krasniqi E, Barchiesi G, Pizzuti L, et al. Immunotherapy in HER2positive breast cancer: state of the art and future perspectives. $J$ Hematol Oncol 2019;12:111.

129 Chaganty BKR, Qiu S, Gest A, et al. Trastuzumab upregulates PD-L1 as a potential mechanism of trastuzumab resistance through engagement of immune effector cells and stimulation of IFNgamma secretion. Cancer Lett 2018;430:47-56.

130 Loi S, Giobbie-Hurder A, Gombos A, et al. Pembrolizumab plus trastuzumab in trastuzumab-resistant, advanced, HER2-positive breast cancer (PANACEA): a single-arm, multicentre, phase 1b-2 trial. Lancet Oncol 2019;20:371-82.

131 Chia S, Bedard PL, Hilton J, et al. A phase lb trial of durvalumab in combination with trastuzumab in HER2-positive metastatic breast cancer (CCTG IND.229). Oncologist 2019;24:1439-45.

132 Kahraman S, Yalcin S. Recent advances in systemic treatments for HER-2 positive advanced gastric cancer. Onco Targets Ther 2021:14:4149-62.

133 Luke JJ, Patel MR, Hamilton EP, et al. A phase I, first-in-human, open-label, dose-escalation study of MGD013, a bispecific DART molecule binding PD-1 and LAG-3, in patients with unresectable or metastatic neoplasms. J Clin Oncol 2020;38:3004-04.

134 Patel M, Luke J, Hamilton E, et al. A phase 1 evaluation of tebotelimab, a bispecific PD-1 x LAG-3 DART $®$ molecule, in combination with margetuximab in patients with advanced HER2+ neoplasms. J ImmunoTherapy Cancer 2020;8:A340-93.

135 Catenacci DV, Rosales M, Chung HC, et al. MAHOGANY: margetuximab combination in HER2 + unresectable/metastatic gastric/gastroesophageal junction adenocarcinoma. Future Oncol 2021;17:1155-64.

$136 \mathrm{Lim}$ SH, Vaughan AT, Ashton-Key M, et al. Fc gamma receptor Illb on target $\mathrm{B}$ cells promotes rituximab internalization and reduces clinical efficacy. Blood 2011;118:2530-40.

137 Roghanian A, Teige I, Mårtensson L, et al. Antagonistic human FcgammaRIIB (CD32B) antibodies have anti-tumor activity and overcome resistance to antibody therapy in vivo. Cancer Cell 2015;27:473-88.

138 Veri M-C, Gorlatov S, Li H, et al. Monoclonal antibodies capable of discriminating the human inhibitory Fcgamma-receptor IIB (CD32B) from the activating Fcgamma-receptor IIA (CD32A): biochemical, biological and functional characterization. Immunology 2007;121:392-404

139 Yonezawa A, Dutt S, Chester C, et al. Boosting cancer immunotherapy with anti-CD137 antibody therapy. Clin Cancer Res 2015;21:3113-20.

140 Ponath P, Menezes D, Pan C, et al. A novel, fully human antifucosyl-GM1 antibody demonstrates potent In Vitro and In Vivo antitumor activity in preclinical models of small cell lung cancer. Clin Cancer Res 2018:24:5178-89.

141 Masu T, Atsukawa M, Nakatsuka K, et al. Anti-CD137 monoclonal antibody enhances trastuzumab-induced, natural killer cellmediated cytotoxicity against pancreatic cancer cell lines with low human epidermal growth factor-like receptor 2 expression. PLOS One 2018;13:e0200664.

142 Gopal AK, Levy R, Houot R, et al. First-in-human study of utomilumab, a 4-1BB/CD137 agonist, in combination with rituximab in patients with follicular and other $\mathrm{CD}^{2} \mathrm{O}^{+}$non-hodgkin lymphomas. Clin Cancer Res 2020;26:2524-34.

143 Liu L, Lam C-YK, Alderson R. Selection of a bispecific trivalent HER2 x CD137 trident format providing optimal tumor-anchored immune co-stimulation. Cancer Res 2019;79:1560.

144 Modi S, Saura C, Yamashita T. Updated results from DESTINYbreast01, a phase 2 trial of trastuzumab deruxtecan in HER2 positive metastatic breast cancer. Cancer Res 2021;81:Abstract PD3-06.

145 Banerji U, van Herpen CML, Saura C, et al. Trastuzumab duocarmazine in locally advanced and metastatic solid tumours and HER2-expressing breast cancer: a phase 1 dose-escalation and dose-expansion study. Lancet Oncol 2019;20:1124-35.

146 Meric-Bernstam F, Hanna D, Beeram M, et al. The safety, antitumor activity, and biomarker results of the HER2-target bispecific antibody ZW25 in HER2-expressing solid tumors. Ann Oncol 2019;30:Abstract 3575:v167-8.

147 Alsina M, Boni V, Schellens JHM, et al. First-in-human phase $1 / 2$ study of MCLA-128, a full length IgG1 bispecific antibody targeting HER2 and HER3: final phase 1 data and preliminary activity in HER2+ metastatic breast cancer (MBC). J Clin Oncol 2017;35:2522.

148 Liu X, Zhang N, Shi H. Driving better and safer HER2-specific CARs for cancer therapy. Oncotarget 2017;8:62730-41.

149 Deng W, Liu J, Pan H, et al. A bispecific antibody based on pertuzumab Fab has potent antitumor activity. $J$ Immunother 2018;41:1-8.

150 Lopez-Albaitero A, Xu H, Guo H, et al. Overcoming resistance to HER2-targeted therapy with a novel HER2/CD3 bispecific antibody. Oncoimmunology 2017;6:e1267891. 